Portland State University

PDXScholar

$1-1-2012$

\title{
Figurative Language in the Immigration Debate: Comparing Early 20th Century and Current U.S. Debate with the Contemporary European Debate
}

Ensieh Biria

Portland State University

Follow this and additional works at: https://pdxscholar.library.pdx.edu/open_access_etds Let us know how access to this document benefits you.

\section{Recommended Citation}

Biria, Ensieh, "Figurative Language in the Immigration Debate: Comparing Early 20th Century and Current U.S. Debate with the Contemporary European Debate" (2012). Dissertations and Theses. Paper 234. https://doi.org/10.15760/etd.234

This Thesis is brought to you for free and open access. It has been accepted for inclusion in Dissertations and Theses by an authorized administrator of PDXScholar. Please contact us if we can make this document more accessible: pdxscholar@pdx.edu. 
Figurative Language in the Immigration Debate: Comparing Early 20th Century and Current U.S. Debate with the Contemporary European Debate

by

Ensieh Biria

A thesis submitted in partial fulfillment of the requirements for the degree of

\author{
Master of Science \\ in \\ Communication
}

Thesis Committee:

L. David Ritchie, Chair

Cynthia-Lou Coleman

Priya Kapoor

Portland State University

(C)2012 


\begin{abstract}
This study analyzes newspaper coverage of immigration reform in mainstream newspapers prior to, and following the debate in June 2007. The newspaper text is analyzed using metaphor interpretation supported by content analysis. The quantitative result categorizes the identified metaphors in three distinct metaphor categories about: immigrants and immigration, immigration policy and enforcement, and metaphors about the debate and immigration issue itself. The relative distribution of metaphors among categories is provided. Using an open coding process, emergent metaphor categories are identified. The qualitative findings describe metaphors and schemas that were potentially activated by particular metaphorical phrases in this context. Lastly, this research compares the similarities and differences of the immigration debate of the early $20^{\text {th }}$ century with the contemporary U.S. and European debate.
\end{abstract}




\section{DEDICATION}

I dedicate my thesis work to my family. A very special feeling of gratitude to my loving husband, Farid Sariosseiri and my wonderful daughter Leila Sariosseiri who have patiently supported me through my journey. Thank you both for supporting me throughout this process. Thank you!

A special thank you to my loving parents, Golnaz Ghorbani-Nik and Hassan Biria who have encouraged me to complete this program. I also would like to thank my sisters, Samaneh Biria and Sara Biria, for their love and support. 


\section{ACKNOWLEDGEMENTS}

I wish to thank my committee members who were more than generous with their time and flexibility. A special thanks to Dr. David Ritchie, my committee chairman for his guidance, encouragement, enthusiasm, and most of all patience throughout the entire process. Thank you for many hours of reading, correcting and reflecting.

I am also indebted to Dr. Cynthia-Lou Coleman for her encouragement to pursue this master's degree and helping me to overcome a few bumps along the way. She was a great support and a friend who was there for me at the beginning and the end of my journey.

I would like to acknowledge and thank Dr. Priya Kapoor for agreeing to serve on my committee. She was very kind and generous with her time.

I would like to thank Molly Major and Valrie Dyhouse for coding my data. Thank you for your time and enthusiasm.

Finally, I would like to thank my sister Samaneh Biria for helping me with various things throughout the completion process. 


\section{TABLE OF CONTENTS}

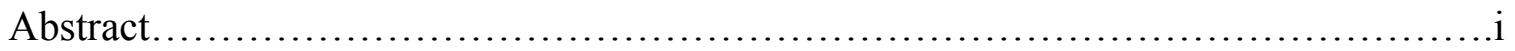

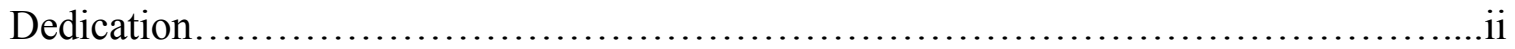

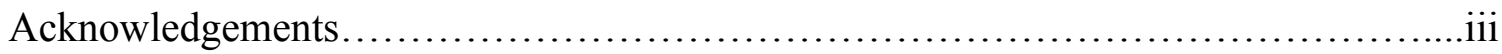

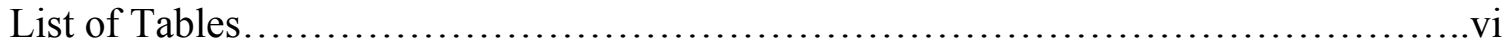

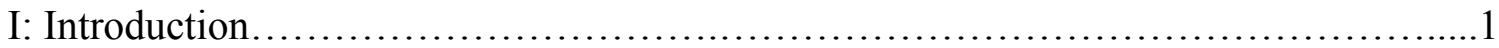

Justification of the Study .............................................

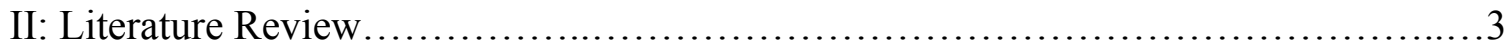

1. Past and present of U.S. immigration debate.......................... 3

2. Immigration debate in Europe....................................

3. Conceptual metaphor theory ................................... 10

4. Previous studies of metaphors used in the debate about immigration.14

- Early $20^{\text {th }}$ century U.S.......................................14

- Contemporary European debate............................... 14

- Contemporary U.S. debate......................................17

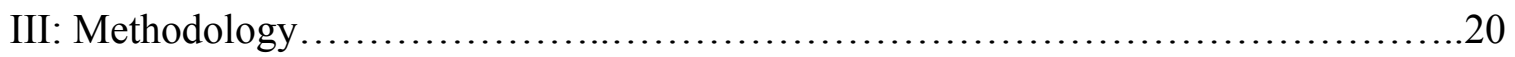

1. Research Questions...........................................20

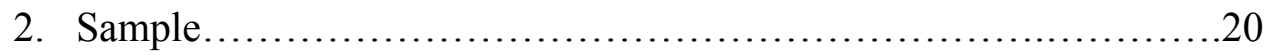

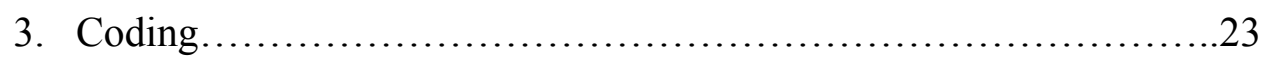




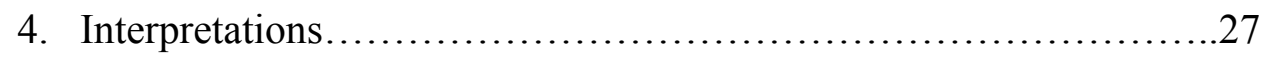

- Quantitative................................................27

- Qualitative.............................................27

IV: Findings............................................................... 33

1. Distribution of metaphors.................................. 33

2. Immigrants and immigration................................ 35

3. Immigration policy and enforcement........................44

4. Debate about immigration issue..............................47

5. Potential schemas.............................................51

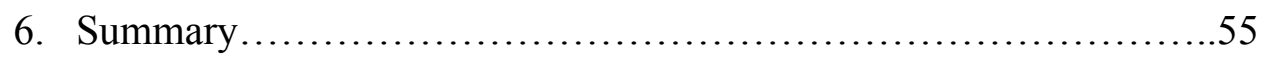

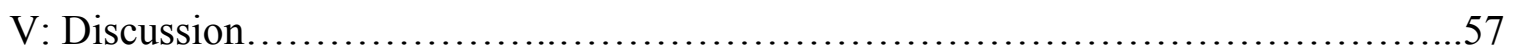

1. Comparisons...............................................57

2. Contrasts................................................... 58

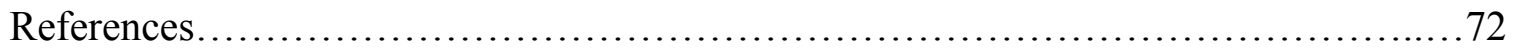




\section{List of Tables}

Table 1: Distribution of metaphors, U.S. Immigration Debate $2007 \ldots \ldots \ldots \ldots \ldots \ldots \ldots . \ldots 34$

Table 2: Representative quotes for major groupings of immigration metaphors.........61

Table 3: Immigration Tropes................................................64

Table 4: Emergent Tropes................................................ 70 


\section{Introduction}

In this study, I will identify dominant metaphors that were used in the most recent immigration debate and analyze their role in shaping the context of this discourse. In particular, I will take a look at the mainstream U.S. newspaper coverage of the immigration reform debate in May and June 2007. The use of figurative language from

the most recent debate is compared to the early $20^{\text {th }}$ century discussion of immigration in the United States and the contemporary debate in Europe.

This research, by illustrating the use of figurative language during two different periods of time in the United States, identifies differences and similarities of themes that shape the context of this debate. Furthermore, the comparison of the findings to the contemporary European debate provides an analysis of metaphors within a different political and cultural context.

This study attempts to gain an understanding of the strategic use of metaphors to construct and shape the context of the immigration discourse in the United States. How issues are presented may in turn influence how readers comprehend complex and contested issues such as immigration. The outcome of this research may provide the groundwork for future research to measure the effect of the figurative language on public opinion and immigration policy outcome.

\section{Justification of the Study}

This study adds to the literature of metaphor analysis with a focus on political discourse, in particular the discourse about immigrants and immigration in the United States. The ultimate aim of this research is to explore the relations between public 
discourse, cognition and society. The immediate objective is to identify conceptual metaphors used to construct the debate over immigration in the U.S.

There is an existing body of research that has studied the role of news media in shaping the public's view (Herbst, 1993; Ladd \&Benson, 1992; Page, 1996). Since the majority of the public relies on news media for information, an awareness of strategic use of language, including figurative language is paramount. Although it is beyond the scope of this paper, this research may provide useful information that can be utilized to measure media's role in shaping and defining public opinion.

Researchers have studied the role of figurative language within the context of the immigration debate and have identified several existing metaphors that are prevalent throughout various studies. However it is evident that some metaphors are prone to change over different periods of time while other metaphors maintain a strong presence and new metaphors continue to emerge. This research aims to fill the gap by identifying new metaphors that may emerge in the recent immigration discourse and evaluate the presence of already identified metaphors. 


\section{Literature Review}

\section{History of U.S. Immigration}

In his book "Essentials of Immigration Law" Richard A. Boswell (2006) provides a brief history of immigration and immigration laws in the United States. He describes immigration laws as a "tide-like shift between restrictiveness and openness toward immigrants" (p. 1). The early 1800's marked the beginning of an "open door" period during which time a large number of Catholics immigrated to the U.S. This period was followed by the post-civil war era, which marked the beginning of a more "restrictive" period in U.S. immigration. The increased demand for labor welcomed the immigration influx of the early $20^{\text {th }}$ century, which then caused a new restrictive immigration system based on specific racial, ethnic, and national preferences. The Immigration and Nationality Act (INA) of 1965 ended the national origins system as part of the civil rights reform and produced an increased influx of immigrants thereafter. Instead of national origin, family relations became a key criterion of gaining admission to the U.S. The comprehensive reform of the late 1970's caused a flow of immigrants and a sudden demographic change. As a result, the majority of American people supported a fundamental change in the immigration policy in order to control and minimize the number of new incoming immigrants. In 1990's the proposals have favored closing the doors by focusing the public's attention on the way immigration affects everything from welfare usage to job availability.

Martin and Midgley (2006) categorize the above period into three major phases of U.S. immigration policies: laissez-faire, qualitative restrictions, and quantitative 
restrictions (p.14). The laissez-fair phase can be compared to the "open door" period of the early 1800's when companies and in particular churches supported immigration to the U.S. The qualitative restrictions post-civil war marked the "close door" period that banned immigration for Chinese nationals until 1943. By 1900 immigrants from southern and eastern Europe were not welcomed to immigrate to the U.S. Furthermore a literacy test was enacted to control the quality of immigrants. The numerical restrictions of annual immigration, enacted through the Immigration Act of 1924, mark the quantitative phase. This was followed by the Immigration and Nationality Act (INA) of 1952 otherwise known as the McCarran-Walter Act, which retains the 1924 national origins quota and establishes a visa preference system based on family relationships and employment needs. Lastly, the INA of 1965 reform eliminated the national origins quota system. Recent Immigration Reforms 1980-2006

Since the 1980's there have been several major changes in immigration laws in response to changes in migration patterns. Between 1980 and 1990, there were three major changes in immigration laws. The Refugee Act of 1980 amended the definition of a refugee to include not only people from the Middle East. The Immigration Reform and Control Act of 1986 (IRCA) were passed in response to the need to prevent or decrease illegal immigration. IRCA imposed employer sanctions on U.S. employers who knowingly hired undocumented migrants. Lastly, the rather liberal Immigration Act of 1990 (IMMACT) increased the number of employer based immigrant visas.

Three major changes also occurred between 1996 and 2006: the Antiterrorism and Effective Death Penalty Act (ATEDPA), the Personal Responsibility and Work Opportunity Reconciliation Act (PRWORA), and the Illegal Immigration Reform and 
Immigrant Responsibility Act (IIRIRA). The ATEDPA simplified the process of detaining and deporting convicted immigrants. The PRWORA limited welfare access for most immigrants unless they were naturalized citizens or met other limiting conditions. Lastly, the IIRIRA introduced measures to decrease illegal immigration by adding border patrol agents and implementing a pilot program for employers to check the legal status of immigrant workers.

The most recent immigration reform was in response to terrorism and illegal migration. In response to the September 11, 2001 attacks, the following reforms were passed: Uniting and Strengthening America by Providing Appropriate Tools Required to Intercept and Obstruct Terrorism Act of 2001 (USA PATRIOT), the Enhanced Border Security and Visa Entry Reform Act of 2002 (EBSVERA), and finally the REAL ID Act of 2005. The USA PATRIOT act granted the U.S. Attorney General to detain and deport any foreigner who would impose a danger to U.S. national security and tripled the number of border patrol agents. The EBSVERA created more strict rules and security for student visa applicants. And lastly the REAL ID Act introduced amendments to asylum law to raise the asylum standards and restrictions on removal. And additionally the law provided that issued driver's licenses may not be accepted by federal agencies for official purposes.

Immigration Reform Today

Following President Bush's speech on Immigration in May of 2006, the House and Senate passed two different bills for comprehensive immigration reform. The stated purpose for the House bill was to prevent terrorism (Bill 4437) and the purpose of the Senate bill was to improve border security and provide a comprehensive plan to address 
unauthorized immigration (Bill 2611). The House called for a plan to build a 698 miles fence along part of the Mexican border costing \$2.2 billion while Republican Senator John McCain and Democratic Senator Edward Kennedy introduced a new legislation to primarily expand the guest-worker program. The bipartisan effort would have allowed undocumented immigrants to stay in the U.S. legally and follow a path to gain citizenship. The draft bill proposed by the House and Senate would need to satisfy the majority in each house and the president. The differences between the two bills were not reconciled and the proposed immigration reform came to a halt. There has been no major movement toward comprehensive immigration reform since this bill died in 2007.

This legislation was significant because it addressed the issue of unauthorized immigration that continues to persist today. Although Mr. Bush's speech emphasized the need to crackdown on illegal immigrants, the real theme of his speech focused on the U.S. as a welcoming society toward immigrants. He states that: "America can be a lawful society and a welcoming society at the same time". He further supported the guest worker program proposed by the Senate and an ultimate path to citizenship as the middle ground between an automatic gain of citizenship and a mass deportation of illegal immigrants. Emphasizing that his solution is not an amnesty, he argues that illegal immigrants who have roots in this country should pay their dues and eventually be able to gain citizenship. Mr. Bush's stance leaned toward a welcoming immigration reform that was ultimately blocked by conservative opposition.

The First Amendment of the U.S. Constitution guarantees the rights of free speech, free press, petition and assembly. These rights provide the opportunity for the public to become involved in the law making process and influence the outcome of laws 
and policies. Along with lobbyist and organized campaigns, the news media (print, radio, $\mathrm{TV}$, internet, etc.) has the opportunity to present stories, editorials, and opinion polls on the proposed policy. The media have the power to shape and influence the public's opinion since the majority of the public receives the news through various sources of media. The public's opinion may also influence stakeholders in the law making process and skew the motivations of the policy makers. Therefore an understanding of the language used by the media to construct and present the news to the public is vital and of primary interest of this study.

\section{Immigration Debate in Europe}

Brief History

After World War II, the majority of northwestern European countries invited 'guest workers' from south of Europe, in particular former Yugoslavia and Turkey, various African and Asian countries, and former colonies to fill low skilled jobs in the booming economy. The number of immigrants continued to increase throughout the 1970 's primarily based on family reunification. The weakened economy of the 1980's resulted in a growing number of unemployed immigrants who continued to remain in their host countries. Additionally the number of immigrants continued to rise with the increased number of refugees from various African and Asian countries in the early 1990's. As a result, there has been a rise in popularity of right-wing parties that favor anti-immigration policies among many European Union members starting in mid 1980's and a shift toward restrictive immigration policies. 


\section{Immigration Debate Today}

In the contemporary European political context, migration has been conceptualized within a security framework that emphasizes a threat to the cultural and economic stability of the nation (Huysmans, 2000). Security related problems such as crime, domestic instability, terrorism, and welfare fraud are often connected to immigration and immigrants. Immigrants and asylum seekers, terms that are used interchangeably, are also perceived as 'fortune seekers' who abuse the welfare system. In addition to losing economic welfare and public security, the immigration discourse is also dominated with the fear of losing national identity.

Various metaphors are used to conceptualize the need for greater security in the context of the European migration debate. A successful metaphor that describes the external borders of the European Union is 'Fortress Europe' (Castan Pinos, 2008) emphasizing the need for safety and security by policing the borders. This metaphor supports a selective immigration policy that excludes outsiders and establishes a clear distinction between insiders and the 'other'. Another dominant metaphor compares the European Union to a 'gated community' (Zaiotto, 2007) by strategically selecting immigrants who can be productive for the society and scrutinizing against illegal immigrants and asylum seekers who can be a burden to the welfare system. Overall the portrayal of immigrants as cultural, economic and national identity threat has been perceived as racist and xenophobic leading to restrictive migration policies in contemporary Europe. 


\section{Summary}

The debate over immigration and immigration policy in the United States and Europe take place within different political and cultural contexts. A review of each period reveals that vivid language, particularly vivid metaphors, is used to conduct this debate. The varying contexts suggest that there are also differences in language that is used to construct the debate. The following research question emerges:

RQ1: "How does the language used in the most recent phase of the immigration debate in the United States differ from the language used in earlier times, and in the contemporary debate in Europe?" 


\section{Conceptual Metaphor Theory}

Metaphor analysis stems largely from the work of Lakoff and Johnson (1980), in which they argue that our conceptual system is metaphorically structured. Most metaphors arise from our physical experiences, which influence our thought processes. From the cognitive linguistic view, metaphors are used to understand one set of concepts in terms of another, which we are familiar with (p. 10). They consist of a source and a target domain (also referred to as the vehicle) with the source as a more physical and the target a more abstract kind of domain. Each metaphor establishes a 'mapping' or a systematic correspondence between the source and target domains. In other words, the reader is able to experience the topic in terms of the vehicle. For example consider the metaphor IMMIGRATION IS A FLOOD. Here the source domain natural disaster makes certain characteristics of flood more salient which consequently structures our experience of the target domain immigration in terms of flood's destructive qualities. The vehicle FLOOD is a metaphorical description of forceful and destructive features of this natural catastrophe. According to Lakoff and Johnson, such metaphoric mappings are major processes of human understanding.

Thibodeau and Boroditsky (2011) demonstrate the effect of metaphors on how people think about an issue and how people attempt to solve an issue. In a number of experiments they highlight that metaphors are used strategically to frame a social problem such as crime. Price, Tewksbury and Powers (1997) argue that the use of such metaphorical framing often leads to inferences that are consistent within the frame structure. Metaphors are used as a framing device to prime a particular cognitive schema, 
a collection of related perceptual simulators of objects or experiences that are most salient in our mind. A frame is constructed of a collection of such schemas that exist in our current cognitive context in which they were most recently activated. The use of metaphors can highlight certain aspects of a frame while downplaying other parts (Schoen, 1979; Jerolmack, 2008). During this process, the 'context-relevant elements of the schema that have been activated through the use of metaphors, suppress the 'contextirrelevant' associations (Ritchie, 2006, p. 106). Thibodeau and Boroditsky's (2011) study concludes that metaphorical frames activate schemas that influence how readers conceptualize abstract phenomenon such as crime. In other words, certain ideas and feelings are activated over others, which evoke particular thoughts and feelings that influence the reader's interpretation of the subject.

Donald Schön (1979) studied the use of metaphors in aiding the construction of public's perception of social policy issues. He claims that metaphors can have an influence on identifying the social problem as well as shaping the discourse to a desired solution (Schön, 1979). Social policy problems are often told through stories and the problems are strategically framed largely through metaphors underlying the stories. These metaphors are used to create new ways of perceiving and understanding the situation. Schön refers to these as 'generative metaphors' that entail conflicting views and strategies to try to resolve policy dilemma (see below an example of the generative metaphor). The stories that are told to describe a situation are consciously formulated in a way to strategically frame social problems and shape public consciousness. These stories are meant to set the direction for problem solving and suggest a prescription for action ( $\mathrm{p}$. 138). 
According to Schön each story creates a social reality through the process of naming and framing in which certain features are selected to become more salient and placed within the frame of a particular context by using generative metaphors (p. 146). For example, SLUMS ARE BLIGHTED is used as a surface metaphor to exemplify the deep metaphor of disease and cure. Once we are able to see that slums are blighted then we can conclude that they must be completely removed by redesigning the entire area because we identify blight with a disease. In order to cure a disease we must completely remove it. Therefore the metaphor SLUMS ARE BLIGHTED identifies the problem as well as suggests a solution and cure to the problem. Another example of SLUMS ARE NATURAL COMMUNITY selects the features of a natural community such as the threat of dissolution and need for preservation and creates a reality of the situation that leads the reader to conclude that areas should be fixed rather than destroyed entirely. These examples describe how metaphors can be used to identify the problem as well as set the direction for a possible solution. Schön claims that framing of social problems is often mediated by reported stories as well as the metaphors underlying those stories (p. 138).

The claim that metaphorical frames activate certain schemas to influence the audience (Thibodeau \& Boroditsky, 2011) can be applied to the public policy debate over immigration. Conceptual metaphors used in the immigration debate may influence how the reader conceptualizes the immigration problem. How the problem is defined and understood can subsequently lead to legitimizing of proposed solutions as well as the kind of information the reader seeks in order to understand the issue. The role of metaphorical framing within the immigration debate leads to the following research question: 
RQ2: "What are the potential influences of immigration metaphors and the schemas they activate on how people think about the issue?" 


\section{Previous Studies of metaphors used in the debate about immigration}

Early $20^{\text {th }}$ century U.S.

O'Brien (2003) found that metaphors and other rhetoric play an influential role in the policy arena. He analyzed the discourse strategies of the immigration restriction debate of the early 20 th century and identified "ORGANISM", "OBJECT", "NATURAL CATASTROPHE", "WAR”, “ANIMAL AND SUBHUMAN" metaphors as the underlying conceptual themes. The ORGANISM metaphor accepted that immigrants come from unsanitary parts of the world and have high fertility rates in the United States. This conceptual metaphor would create a fear of spread, contamination and decomposition. Immigrants as OBJECT metaphor represented them as MATERIAL with characteristics of cheap labor. In many instances immigrants were replaceable by new machinery. The NATURAL CATASTROPHE metaphor used FLOOD as the overwhelming rush of immigrants, which would consequently create a threat to the American character. WAR metaphor entailed an us-against-them imperative supported by the notion that immigrants refuse to assimilate and were regarded as INVADERS of the country. Finally, the ANIMAL and SUBHUMAN metaphors represented immigrants as less civilized than native Americans. O'Brien argues that such metaphoric themes can have an effect of supporting repressive public policies against marginalized groups.

\section{Contemporary European Debate}

In her study of the UK immigration debate, Wodak (2006) illustrates how two different concepts, "immigrant" and "asylum-seeker", have been mixed up in UK media to produce the terms "illegal asylum-seekers", "illegal immigrants", "illegal refugees", 
“economic immigrants”, “economic refugees”, "bogus-asylum seekers”, and "asylumbombers". The mixing of these concepts has shaped the immigration discourse in a way that the public no longer distinguishes between the two distinct groups of immigrants. Although immigrants and asylum seekers are both seeking permanent residence in the UK, their economic conditions as well as their residency requirements vary. In other words, asylum seekers may receive government assistance while other immigrants will have to provide proof of financial ability in order to obtain immigrant visa status.

Therefore the public may view asylum applicants as an economical burden to the country and apply the same conceptualization to the other immigrant groups. The role of the media in the shaping of this context is important because the media has the ability to construct the discourse in a way that would influence people's understanding of these concepts. Wodak claims that the construction of this particular context supports and legitimizes stricter immigration and asylum policies.

Van Dijk (2001) has also focused on the importance of context in discourse studies. He claims that context "consists of such categories as the overall definition of the situation, setting (time, place), ongoing actions (including discourses and discourse genre), participants in various communicative, social or institutional roles, as well as their mental representations: goals, knowledge, opinions, attitudes and ideologies. Thus context emphasizes the importance of society and social practices in discourse analysis. In the examination of the discourse strategies of the Spanish Secretary of the Interior in response to the expulsion of a group of African illegal immigrants from Melilla (Martin Rojo \& Van Dijk, 1997), the authors illustrate how discourse strategies can legitimize political action. They find out that the positive self-presentation and negative other- 
presentation legitimizes 'our' actions and policies as beneficial and 'their' action as threatening to the country. The mayor's speech creates a positive self-image of himself as a law-abiding democrat while creating a portrayal of the immigrant as a criminal and a threat to the nation. Discursive strategies of this nature exclude the 'others' from the nation or the 'in-group'.

Del-Teso-Craviotto (2009) also finds that the Spanish media's strategic use of discursive strategies describes immigration primarily in terms of its otherness. By examining the discursive strategies of an Internet forum for Argentines in Spain, he illustrates the media's construction of the 'out-group'. The analysis of the discourse among the marginalized group (immigrants from Argentine) confirms that the participants accept racist ideologies that dominate the mass media. Similar to other xenophobic contexts, the Spanish discourse on immigration also focuses on the threat presented by the 'outgroup'.

The negative 'other' presentation is also found in Van Der Valk's (2003) examination of the right-wing political discourse on immigration in France. Immigrants are often perceived as potential fraud abusing the welfare system and the laws. One of the most prominent metaphors in the French right-wing discourse on immigration and nationality are metaphors of AGGRESSION and WAR. These metaphors refer to the danger and the risk of losing control over immigration. Another common metaphor is WATER also symbolizing loss of control over immigration process. TRAFFIC metaphor conceptualizes immigrant's easy way of obtaining resident permits. And lastly the HOUSE metaphor refers to limited restriction on immigration. Van Der Valk asserts that these metaphors reinforce the belief that immigration is a threat and danger to national 
identity and there is a lack of control over immigration. The right-wing political discourse is dominated by the negative other-presentation of the immigrant groups who are also portrayed as criminals breaking the French laws.

Charteris-Black (2006) analyzed the British right wing political communication and media reporting for references to immigration and found two main metaphors in relation to immigration in the spoken and written sources they studied. The first, "NATURAL DISASTER" relating to the most common form of natural disaster such as floods and tidal waves and the second, "CONTAINER" metaphor since containers frequently contain fluids and could build up pressure. Both metaphors discourage empathy with immigrants by treating them as objects rather than as the subject of life stories. In most cases, writers use liquid metaphors to relate to emotional domain in order to influence powerful emotions such as fear and the desire for protection. Charteris-Black argues that both types of metaphors have persuasive subliminal effects, which contribute to legitimizing right wing political agenda.

\section{Contemporary U.S. Debate}

Mehan (1997) and Santa Ana $(1998,1999)$ study the recent immigration debate in the United States. Mehan analyzed the discourse strategies of proponents and opponents of the immigration debate over California's Proposition 187, which would deny undocumented immigrant children public services such as schools and health care. Two discourse strategies were identified: "the enemy or one of us?" and "are we all in this together or is it us vs. them?" Mehan identified the use of indexical expressions or deictic markers such as 'we' and 'here' which help to create a shared sense of community, while the use of other indexical or deictic such as 'us' and 'them' can be used to exclude or 
insult. The study concludes that the proponent's stories of 'illegal aliens' taking jobs and abusing social services and appealing to self-interest of citizens were more compelling and effective than the opponent's rational argument supported by statistical evidence.

Santa Ana's (1999) metaphor analysis of the print media texts of California's proposition 187 identified IMMIGRANTS ARE ANIMALS as the main metaphor used to characterize immigrants as individuals in public discourse. Santa Ana also highlighted two metaphors that were previously identified by Chilton (1996) to conceptualize the U.S., namely the NATION AS BODY and NATION AS HOUSE metaphor. In the first, the immigrant is characterized as a disease troubling the body and in the second as dirt to be swept out. Other minor immigrant metaphors were IMMIGRANTS ARE DISEASED PEOPLE and IMMIGRANTS AS WEEDS. Santa Ana concludes that the underlying metaphor IMMIGRANTS ARE ANIMALS leads to entailments and mappings that are racist. Furthermore he claims that the lack of positive dominant metaphors support his finding that public discourse on immigration is racist.

Existing studies have identified underlying conceptual metaphors that shape the immigration discourse. The reviewed studies analyze discourse within different cultures, languages and overall contexts. The NATURAL DISASTER or CATASTROPHE metaphor is identified by a few studies as a deep metaphor underlying metaphors such as 'being inundated by', 'flooded by', and 'tidal waves (Wodak, 2006; O’Brien, 2003). Another commonly used trope is the CONTAINER metaphor (Charteris-Black, 2006), which is built on the NATION AS BODY and NATION AS HOUSE metaphor (Chilton, 1996). ORGANISM, OBJECT, WAR, WEEDS, and ANIMAL are also prominent metaphors primarily in discourse of earlier times (O’Brien, 2003) with the exception of 
WAR and ANIMAL metaphors that also appear frequently in the contemporary debate (Santa Ana, 1999). Lastly, the US vs. THEM discourse strategy is used to exclude and insult the 'other' group (Mehan, 1997).

The prevailing characterization of immigrants and immigration in the context of U.S. and European public discourse has produced negative entailments and legitimized stricter immigration policies in the last decades. The literature review reveals that the dominant metaphoric representation of immigrants and immigration are transnational. There are similarities and differences between the prominent metaphors in the U.S. and the European immigration discourse. Furthermore, it appears that metaphors are not fixed and prone to change. Metaphors such as ORGANISM, OBJECT, and WEED are clearly less prevalent in today's immigration discourse. These findings lead to the following research questions:

RQ3: "How do the metaphors in the recent U.S. debate compare to metaphors in earlier debate?"

RQ4: "How do the metaphors in the recent U.S. debate compare to metaphors in the recent European debate?" 


\section{Methodology}

\section{Research Questions}

The principal methodology used in this thesis is metaphor analysis supported by content analysis. In particular, the main focus was on identifying figurative language used in the most recent immigration debate and analyzing the potential influence on creating cognitive schemas that could affect the public's opinion formation. Additionally, this study compares the identified metaphors in the current debate to earlier immigration debate in the United States as well as the contemporary debate in Europe. The following research questions have emerged:

RQ1: "How does the language used in the most recent phase of the immigration debate in the U.S. differ from the language used in earlier times, and in the contemporary debate in Europe?"

RQ2: "What are the potential influences of immigration metaphors and the schemas they activate on how people think about the issue?"

RQ3: "How do the metaphors in the recent U.S. debate compare to metaphors in earlier debate?"

RQ4: "How do the metaphors in the recent U.S. debate compare to metaphors in the recent European debate?"

\section{Sample}

Historically immigration laws have shifted between open and restrictive policies toward immigration and immigrants. In the 1990's proposals have focused the public's attention on the way immigration affects job availability, welfare usage, and safety of 
American people (terrorism). The legislation proposed in the most recent round of debate addressed the issues of unauthorized immigration, which continues to be a primary immigration concern today. While Mr. Bush's speech emphasized the need to solve the illegal immigration problem, the overall theme of his speech conveyed the message that America is a welcoming society to immigrants. The new legislation would provide a "fair path to legalization" for the approximately 12 million undocumented immigrants currently in the United States.

The Project for Excellence in Journalism's (PEJ) report: "News Coverage of Immigration 2007", provides an overall look at the coverage in all media sectors. The indepth analysis covers news coverage of 70,737 stories for the entire year of 48 media outlets across 5 media sectors. It shows that the immigration coverage in the first four months of the year was below $2 \%$ followed by a sudden surge in May and June when the coverage jumped to $6.1 \%$ to $7.6 \%$, respectively. The coverage decreased to $2-3 \%$ for the remaining of the year. Based on the PEJ's report, the time period for this study is narrowed to two months before and two months after the immigration coverage peak in May and June 2007. Thus this study examines the immigration news coverage during the period from March to August 2007.

The representative set of text includes newspaper coverage during the chosen period of time. According to the PEJ report, immigration debate was the biggest story for newspapers in May and June, filling $8 \%$ of the front-page coverage followed by $7.5 \%$ of campaign coverage and $7.1 \%$ content about events in Iraq. The sources picked for this study are newspaper of records with a large circulation and therefore highly influential and publicly available. The Lexis-Nexis database search identified relevant newspaper 
articles of national newspapers including the New York Times, Washington Post, USA Today, and The Christian Science Monitor. A search for the word "immigration" and "immigrant" produced a number of articles found in each of the newspaper sources. Selected for inclusion in this analysis are only stories that deal with the debate over immigration reform. Stories that contain the search terms in a different context are excluded as well as letters to the editor because this study focuses on newspaper coverage of the immigration debate itself. Therefore immigration articles within a different context are considered as irrelevant and were excluded from the study. The remaining stories were all coded. The total number of articles coded include: New York Times N=32, Washington Post N=19, USA Today N=6 and The Christian Science Monitor N=22. As a final note regarding the choice of newspaper articles, it should be mentioned that the above listed mainstream newspapers were selected because they were most likely to report the theme of immigration through traditional journalistic practices with a commitment to "accuracy, balance, checks on pure profit maximization, democratic accountability and editorial separation" (Entman, 2005:54). The analysis of the present research reveals that the journalists of the selected mainstream newspapers engage in a somewhat balanced and neutral reporting of the immigration discourse. It is evident that there are fewer metaphors present in the actual reporting by the journalist themselves. While attempting to maintain a balanced reporting, the journalists provide direct quotes from both sides of the debate whereby the majority of the metaphoric language is reported. 


\section{Coding}

According to Lakoff and Johnson (1990), metaphors consist of a target and source domain. Conceptual metaphors are used to understand abstract (target) concepts in terms of more concrete experiences (source) that we are familiar with. Metaphors establish numerous mappings between the domains. For the purpose of this study, metaphor is operationalized as a device for seeing something in terms of something else or also referred to as the vehicle. The vehicle is the identifying feature of a metaphor describing the abstract concept in terms of something more familiar.

\section{Codes}

A list of metaphor categories identified in previous research, reviewed in Chapter 2, was assembled to assist the coders. The major conceptual metaphor groupings from previous research are operationally defined below. A table of representative quotes of major conceptual metaphor groupings with cited examples was included in the codebook (see Table 2) to further reinforce the definition of each category.

\section{"Organism"}

In the organism metaphor, the social community is compared to the physical body. Metaphors related to disease as well as metaphors, which describe and relate to discomfort (digestion and absorption). For example: "We have begun to gag a bit over the size and quality of the dose" (O’Brien, 2003).

\section{"Object"}

This conceptual metaphor views immigrants as impersonal and interchangeable objects; also as (raw) material and cheap labor that can be replaced. For example: "We 
have got to take out the lumps or break them up and smooth out the mass" (O'Brien, 2003).

"Water"

Flood metaphors are commonly used to portray an image of excessive flow or wave of water to describe an increase in the rate of migration as well as the destructive nature of flood. For example: "Incoming tides threaten to overwhelm us with the magnitude and ceaseless oncoming of its flood" (O’Brien, 2003).

"War/Enemy"

War metaphor views immigration as an invasion of the country and the immigrants as invaders. Enemy metaphor refers to immigrants as aliens and in particular illegal aliens; people outside of our society who are foreign and threatening our lives (terrorists) and perhaps the quality of our life. For example: "Armies equal in size to the one we sent to France land every two years on our shores" (O’Brien, 2003).

"Animal"

This trope is used to refer to immigrants as animals who can be lured or baited. Immigrants are also seen as animals that can be attacked, hunted and eaten. For example: "The truth is, employers hungering for really cheap labor hunt out the foreign workers" (Santa Ana, 1999).

"Plant"

This metaphor refers to immigrants as plants, in particular weed that can grow out of control. For example: "We see it as our responsibility to weed out illegal aliens" (Santa Ana, 1999).

"Us vs. them" 
Use of indexical expressions or deictic markers such as 'we' and 'here' to create a shared sense of community while 'us' and 'them' is used to exclude and insult. Their gain is our loss. This condition is represented as us v. them. For example: "While our own citizens and legal residents go wanting, those who choose to enter our country illegally get royal treatment at the expense of the California taxpayer" (Mehan, 1997).

\section{"Container"}

This rhetorical device is used to refer to the nation as what is inside the container (a bounded area), which must be protected and kept secure from external dangers (maintaining the security of borders). For example: "Britain is full up and the government of Britain has as its first responsibility the welfare, security and long-term preservation of the native people of Britain" (Charteris-Black, 2003).

In addition to the existing metaphor categories, the study expected that new categories might emerge from the data. The codebook provided instructions for the coders to identify new emerging metaphors by using an open coding process. Emergent metaphors were listed on the code sheet in a separate column.

\section{Coders}

Two graduate students were recruited from the Communication Department at Portland State University to code the selected sample articles $\mathrm{N}=79$. In order to ensure high reliability of coding, a current student and a past student were selected who had at least completed an introductory course in metaphor studies. The frequency of the selected coder population was deemed adequate to ensure a replicable recording process (at least two independent coders). Intercoder reliability was not computed for this study. Within 
the framework of this research, the level of disagreement in coding process would not significantly alter the outcome.

Each coder was provided with a codebook including specific instructions to guide them through the coding process. The codebook provided the coders with a working definition of metaphor followed by a detailed section about the procedure for metaphor analysis in order to prime them for the analysis (Cameron, 2003). To ensure clarity, the codebook also entailed a section with examples of fuzzy and unclear metaphor categories. The last part of the codebook provided the coders with a list of main conceptual metaphor categories (codes) as operationalized for this study. Additionally the coders were provided with actual examples of main conceptual categories from the reviewed literature (Table 3). While the examples of existing metaphor categories were provided to the coders as a guide, coders were also instructed to identify new metaphors that emerged through open coding (Table 4).

Once the coders had started the coding process, it was necessary to meet and address several questions in order to ensure inter-coder reliability. Prior to the meeting, the coders provided each a list of their questions and a list of the emerging metaphor categories. Upon review of the questions and the newly emerged categories, I added additional instructions to the codebook to reflect the needed clarifications and the new metaphor categories. At the meeting with the two independent coders, the new instructions were presented and questions were answered. The following new metaphor categories emerged from open coding of the sample: "journey", "perception", "structure", "heat", "increase", "decrease", and "sport/game" metaphor. These categories were added to the coding sheet. 


\section{Interpretation}

\section{Quantitative Interpretation:}

The present analysis of figurative language used in the most recent immigration debate is supported by content analysis. The analysis provides the relative distribution of metaphors among different metaphor categories. A list of previously identified metaphor categories in the context of immigration debate is included in table 3. Additionally the study identifies a list of newly emerged metaphor categories from the sample data. Table 4 provides a list of the emergent metaphors.

\section{Qualitative Interpretation:}

The quantitative analysis provides important information about the metaphor categories as well as the distribution of metaphors among different categories. The qualitative section describes the entailments of the underlying metaphorical phrases within different cultural and immigration debate contexts. Additionally, this section identifies cognitive schemas that were potentially activated by particular metaphorical phrases in prior studies.

The NATURAL DISASTER metaphor category exists throughout the immigration discourse (Charteris-Black, 2006; Wodak, 2006) within various contexts. Disaster metaphors often relate to the behavior of WATER and fluid in general. In the analysis of the UK political debate on immigration in 2004, Wodak identified metaphors such as "being inundated by" or "flooded by" as dominant disaster metaphors used to produce related context- and event models. Similarly, Charteris-Black analyzed the British right-wing political communication and identified metaphoric words such as "flow" and "wave". Such words entail the image of excessiveness and as a result 
discourage empathy with immigrants by treating them as objects rather than as the subject of life stories. Furthermore, rivers, waves and tides move around and therefore are related to the primary conceptual metaphor of CHANGES ARE MOVEMENTS. A possible interpretation of this metaphor is that lack of control over change is lack of control over movement. In most cases, writers also use liquid metaphors to relate to emotional domain in order to influence powerful emotions such as fear and the desire for protection from natural disaster.

The CONTAINER metaphor is used to refer to the nation as what is inside the container (a bounded area), which must be protected and kept secure from external dangers (maintaining the security of borders). Charteris-Black (2006) finds a connection between the NATURAL DISASTER and CONTAINER metaphor in that the former is often related to fluid and the latter commonly contains fluid. He argues that the conceptual link between the two metaphors activate both disaster and container schemas and further claims that "the emotion of fear can be aroused by disaster and containment scenarios through the perforation of a boundary around the container allowing the inflow or outflow of liquids" (p. 569). A sudden excessive flow of fluid in a bounded area raises the fluid level and consequently the pressure in the container, which as a result invokes a feeling of loss of control and fear. Santa Ana (1999) also highlights two metaphors that were previously identified by Chilton (1996) to conceptualize the United States, namely the NATION AS BODY and NATION AS HOUSE metaphor. In most cases, writers use liquid metaphors to relate to emotional domain in order to influence powerful emotions such as fear and the desire for protection. Additionally, movement of people across borders is represented as weakening the CONTAINER because it could lead to social 
change. Charteris-Black (2006) argues that both types of metaphors have persuasive subliminal effects evoking cultural and historical experiences related to invasion and as a result contribute to legitimizing right wing political agenda (p.579). This rhetorical figure is commonly used to support restrictive immigration agenda as it relies on the underlying assumption that there are clear boundaries that limit everyone's access to our HOUSE.

In the ORGANISM metaphor, the social community is compared to the physical body. Metaphors related to disease as well as metaphors which describe and relate to discomfort (digestion and absorption) are frequently used to establish a connection between disease and immigrants. The ORGANISM metaphor assumes that immigrants come from unsanitary parts of the world and infest our communities with disease. Furthermore, it associates high fertility rates among immigrants with crowding and taking over our communities. This conceptual metaphor creates a fear of spread, contamination and decomposition within the community. In his analysis of the discourse strategies of the immigration restriction debate of the early $20^{\text {th }}$ century, O'Brien (2003) identified ORGANISM metaphor as one of the underlying conceptual themes. O'Brien argues that such metaphoric themes can have an effect of supporting repressive public policies against marginalized groups.

The conceptual metaphor OBJECT views immigrants as impersonal and interchangeable, as well as (raw) material and cheap labor that can be replaced. O'Brien (2003) identified the OBJECT metaphor in his study and claims that in many instances immigrants were replaceable by new machinery. For example the cheap Chinese labor was once welcomed to help build the railroads. Upon completion of their work, Chinese immigrants were seen as obsolete to the society. It was further assumed that many of the 
immigrants refused to assimilate into American life. O'Brien argues that the OBJECT metaphor and other rhetoric can have an effect on supporting repressive public policies against marginalized groups. Similar to the ORGANISM metaphor, the OBJECT metaphor was commonly used within the context of the early $20^{\text {th }}$ century immigration debate.

WAR metaphor views immigration as an invasion of the country and the immigrants as invaders. Metaphors such as "armies", "invader" and "conquer" conceptualize immigrants and immigration in the context of a battle zone. Closely related to the WAR metaphor is the ENEMY metaphor, which refers to immigrants as terrorists who are encroaching upon in a way that threatens our lives and disturbs the quality of our life. The term "terrorists" may also evoke strong emotional responses particularly after the event of September $11^{\text {th }}$ terrorist attack in New York City. O'Brien (2003) claims that the WAR metaphor entails an 'us against them' scenario, which is supported by the notion that immigrants refuse to assimilate. Thus the WAR metaphor could invoke strong emotional responses in the American people that could ultimately result in supporting a restrictive immigration policy.

The "us vs. them" scenario is often used in connection with the WAR metaphor to establish that the immigrants are marginal to the society. Within the context of the European debate, it is used to create a need for protection from the 'others' by creating a shared sense of community within the 'in-group' while excluding and insulting the 'outgroup'. The two discourse strategies identified by Mehan (1997) are: "the enemy or one of us?" and "are we all in this together or is it us vs. them?" 
The metaphor IMMIGRANTS ARE ANIMALS (O’Brien, 2003; Santa Ana, 1999 ) is used to refer to immigrants as ANIMALS to be "lured" or "baited". Immigrants are also seen as animals hunted and attacked by the American industry and Immigration agents. These metaphors portray the immigrant as less human and as a result not subject to civil rights and human rights. Furthermore, uncontrolled and wild animals generally create a sense of fear in humans. Santa Ana claims that the underlying metaphor IMMIGRANTS ARE ANIMALS leads to entailments and mappings that are racist.

The metaphor category PLANT conceptualizes the immigrant in terms of plants, in particular weed that can grow out of control (Santa Ana, 1999). Some of the metaphors that were identified by Santa Ana are "uproot", "new crop" and "spring up". Although these metaphors are secondary and not very common, Santa Ana claims that they lack positive entailments and degrade immigrants. This metaphor supports Santa Ana's findings that public discourse on immigration is generally racist because it dehumanizes immigrants.

The qualitative review of the previous studies unfolds important information about the patterns, differences and similarities of the use of figurative language in the immigration discourse during different period of time as well as different cultural and political contexts. While the immigration discourse of the early $20^{\text {th }}$ century in the U.S. conceptualized immigrant primarily in terms of ORGANISM, OBJECT, MATERIAL and ANIMAL, the contemporary U.S. discourse focuses on creating an image of immigrants as INAVADER entering the CONTAINER (the nation) and a threat to the people inside the nation. As such the fear of disease and contamination of earlier times is replaced by the fear of the enemy invading our country. It appears that the choice of 
metaphor use is related to the current political and cultural climate of the country. As such the use of prominent metaphors of the early $20^{\text {th }}$ century were affected by the changing demographics of the U.S. population caused by the immigration influx as a result of the increased demand for labor. Subsequently conservative measures were proposed to restrict immigration system based on specific racial, ethnic, and national preference. Similarly, contemporary U.S. studies about restrictive California Proposition 187 discourse reveal metaphors that are perceived as racist.

Overall the majority of the metaphors used in the immigration debate seem to be transnational. Most of the metaphors that appear in the context of the U.S. debate also seem to be common in the contemporary immigration debate in Europe. However it is clear that the discourse in the European context draws a clear distinction between the 'ingroup' and the 'out-group', which is primarily supported by the need to preserve national identity. Also the discourse in Europe often refers to economic burden of asylum seekers as one of the reasons to reinforce the need for restrictive immigration policies. 


\section{Findings}

The results of the content analysis present the relative distribution of each metaphor category in the present study. Table 1 provides a summary of the representative metaphors and the percentage of the relative distribution of each metaphor in the sample data. This table also includes new metaphor categories that emerged from the open coding process. Table 2 illustrates all the metaphor categories that were identified from prior research. This study reveals that the JOURNEY, WAR/ENEMY, and CONTAINER metaphors were among the most commonly used tropes within the context of the most recent debate. The DISEASE metaphor was the least frequently used category.

The various metaphors are used consistently in reference to a certain aspect of the debate. For example the WATER metaphor is generally used to describe the process of immigration while the emergent metaphor SPORT/GAME primarily refers to the debate and the immigration issue itself. As a result, this study distinguishes between three different aspects of the debate. First, metaphors about immigrants and immigration describe the process of immigration and the immigrants themselves. These metaphors include JOURNEY, WAR, WATER, OBJECT, ALIEN, ANIMAL, and DANGER TO THE IMMIGRANT. The 'us vs. them' imperative is often used to make a clear distinction between the citizens and permanent residents of the U.S. and the 'other' group primarily referring to undocumented immigrants. The second group of metaphor refers to immigration policy and enforcement. Metaphors such as AMNESTY, CONTAINER, and INCREASE are often used to describe the need for restrictive immigration policy and increased enforcement. And lastly, metaphors that refer to the debate and the immigration issue itself are categorized in one group. Some examples within this category include 
DISEASE, ORGANISM, PERCEPTION, STRUCTURE, HEAT, DECREASE, and SPORT/GAME metaphor.

Table 1. Distribution of metaphors, U.S. Immigration Debate 2007 (relative frequency table in $\%, \mathrm{~N}=715$ )

\begin{tabular}{ll}
\hline Tropes & Total \\
\hline Journey & 16.6 \\
War/Enemy & 16.1 \\
Container & 8.1 \\
Structure & 8.0 \\
Increase & 6.7 \\
Object & 5.6 \\
Us vs. them & 5.5 \\
Water & 5.5 \\
Organism & 4.8 \\
Animal & 4.2 \\
Alien & 3.5 \\
Heat & 3.0 \\
Plant & 2.9 \\
Perception & 2.9 \\
Decrease & 2.5 \\
Disease & 2.2 \\
Sport/Game & 1.8 \\
\hline
\end{tabular}


This section reviews the identified conceptual metaphors within each of the three categories to illustrate the distinction between the metaphor types. Additionally, this section describes potential influences of immigration metaphors as well as the schemas they activate on how people think about the issue.

\section{Immigrants and Immigration}

\section{JOURNEY}

The Comprehensive Immigration Reform Act of 2007 or otherwise referred to as the Secure Borders, Economic Opportunity and Immigration Reform Act was discussed and failed in the month of June that year. The bill offered a compromise between providing legal status and a path to citizenship for undocumented immigrants and increased border enforcement. A dominant metaphor within this context was the "journey" metaphor, which occurred relatively consistently throughout the sample data. Metaphors such as "stepping forward and start down the path to legalization", "immigrants would come forward to register", "offers a path to earned citizenship", "immigrants to move toward citizenship" were among the most commonly used phrases. Table 3 provides a sample of some of the journey metaphors that were identified.

IMMIGRATION IS A JOURNEY metaphor leads us to see that the process of immigration consists of a path with a goal, direction and progress in stages towards the ultimate goal. A further entailment of this metaphor is that the path of a journey is a surface and therefore the path of immigration is a surface. Anyone who wants to stay on this path must remain on the surface, follow the path and ultimately reach the goal. The journey metaphor sets a direction toward the eventual goal of becoming a U.S. citizen. 
The bill would have provided a guided direction for undocumented immigrants to gradually make a progress in stages toward this goal. For example, one step required the immigrant to pay a fine and eventually leave the country in order to apply for citizenship in the U.S. Furthermore, in order to stay on the path, undocumented immigrants have to remain on the surface, "step forward" and "come out of the shadows" and "into the sunlight" to fulfill the requirements. A quote from Senator Trent Lott says: "If you cower in the shadows, you'll get pummeled. You've got to stand up' (CSM, May 25, 2007). It appears that the "journey" metaphor is predominantly used within this discourse to help create the context of the new immigration bill as positive step toward fixing our immigration problem. As illustrated above, the "journey" metaphor indirectly identifies the problem (undocumented immigrants in the shadow) and sets a direction for possible solution (pay fines, leave the country and apply for citizenship after the required period of time spent as a permanent resident). The “journey” metaphor is similar to Schoen's generative metaphor (Schoen, 1979), which is formulated in a way to strategically influence public's perception of a social problem and ultimately lead the direction of the desired policy outcome. Additionally, this can be compared to Chilton's (1996) claim that metaphorical entailments create conceptual schemes that produce legitimizing discourse to shape policies. Within this discourse, the "journey" metaphor establishes a connection between the 12 million undocumented immigrants (the problem) and the proposed new legislation (the solution) whereby both take a step forward toward solving the current crisis. Essentially, what is occurring is the linking of metaphors such that they constitute a favorable direction of the discourse toward a positive outcome of the proposed policy changes. Metaphors like "coming out of shadow' and 'start down the path to 
legalization" create conceptual schemas in which it appears to be a legitimate step to proceed with the new legislation in order to fix the immigration problem.

$\underline{W A R}$

In the sample newspapers, the immigrants are often represented as the invading enemy threatening the American culture and society. Immigration is a battle zone that requires military action to keep it under control. An example of the WAR metaphor in a New York Times (NYT) article printed on April 5, 2007:

"The operation was the latest in a string of raids by agents from Immigration and Customs Enforcement on companies accused of employing illegal immigrants who, in some cases, are alleged to have stolen the identities of American citizens to create false identification documents."

This example clearly illustrates the WAR metaphor within the context of

this debate. Here the token operation refers to a planned military action that was executed by the Immigration and Customs Enforcement officers. String of raids evokes an image of a series of sudden invasion by officers of law to catch the enemy (immigrants). A reference to a military operation is also made in the next example from the NYT, August 10, 2007:

"They said federal agents would fan out across the country to hunt down alien fugitives who had been ordered to leave the United States but failed to comply."

Just like soldiers, the federal agents spread out across the country to arrest

the enemy. In a different article, the noun 'trigger' evokes the WAR metaphor.

The New York Times article dated May 22, 2007 states:

"Border Security and triggers: several border enforcement measures, known as triggers, must be in place before a temporary worker program can begin. After the triggers were in place, former illegal immigrants could complete their applications." 
Generally, the term 'trigger' suggests an association with guns or an event that causes the start of something to happen, usually something bad. Images of military action, invasion, enemy, gun trigger and events that start a series of other negative events build a mental picture of a war arena.

In another example immigration is described as a threat to the entire society and as a 'war' between cultures:

"The impact of immigration - legal and illegal - on jobs, schools, health care, the environment, national security, are all very serious problems. But more serious than all of them put together is the threat to the culture. I believe we are in a clash of civilizations", said Mr. Tancredo. (NYT, June 24, 2007).

In this case, 'clash of civilization' refers to a theory developed by Samuel P. Huntington, which claims that the primary reason for conflict, in the future, among civilizations are cultural differences. The speaker feels threatened by the existence of the different cultures and believes that the other cultures do not assimilate into the American culture and eventually are in such majority that they can harm the American culture and identity. The immigrants are taking over and invading this civilization thus creating a potential 'war' between different 'cultures'.

WATER

Conceptual metaphors relating to natural disaster have been dominant within the immigration discourse (Charteris-Black, 2006; Chilton \& Ilyin 1993; O’Brien, 2003; Semino \& Masci, 1996). The most common metaphors are associated with excessive flow of water including 'flood' and 'tidal waves'. Consider the following examples: 
"Critics fear a flood of recruits lured solely by the promise of legal status" (WP, May 22, 2007).

"The recent wave of immigration was the largest invasion in the history of the world" (WP, June 17, 2007).

These metaphors conceptualize immigration in terms of excessive flow of water with forceful and destructive abilities. Large quantities of immigrants enter the country like an ocean wave causing a sudden movement, which can be overwhelming for the residents of the country. Metaphors such as CHANGES ARE MOVEMENTS have been identified as underlying metaphors of NATURAL DISASTER (Chilton \& Ilyin, 1993; Semino \& Masci, 1996). Furthermore, natural disaster can cause an intense feeling of emotions for the people who are being flooded by immigrants. This feeling might be intensified when two different metaphors are combined in the same sentence that evokes a 'fear a flood' and 'wave of largest invasion' (FLOOD and WAR).

The build up of emotions caused by a natural force (flood) can be further analyzed through the underlying metaphors of EMOTIONS ARE FORCES and EMOTION IS INTERNAL PRESSURE INSIDE A CONTAINER. The latter metaphor assumes that PEOPLE ARE CONTAINER and EMOTION IS A SUBSTANCE IN A CONTAINER (fluid). These metaphors establish the mapping that the level of fluid is directly related to the pressure inside the container. In other words, if the level of substance rises, the emotional level intensifies and vice versa. (Koevecses, 2003, p.66). Applying this concept to the NATION IS A CONTAINER metaphor within the immigration context, it can lead to the entailment of floods created as a result of excessive immigration 
causing a build up of intense emotions among the people in the nation which consequently can cause the overflowing or explosion of the container. Thus a conceptual link exists between the WATER, WAR and CONTAINER metaphor within the context of this debate.

\section{US VS. THEM}

The US vs. THEM imperative has been identified as particularly effective in stories that exclude the 'other' from the community (Mehan, 1997) and create a picture of immigrants as illegal, criminal, and dangerous.

"Beyond the cost, Mr. Spano said public safety was at risk. 'Having these individuals in our communities is a serious and ongoing threat to the safety of our residents', he said" (NYT, April 29, 2007)

"We want them out of county jails and into federal prisons ASAP, he said" (New York Times March 1, 2007)

"Anytime you have someone who shouldn't have been here in the first place, someone who's violated the law, they should be looking over their shoulder," says Ira Mehlman, a spokesman for the Federation for American Immigration Reform. "They should be nervous and not be made to feel comfortable here."

These examples suggest undocumented immigrants are not part of the community because they jeopardize the safety of citizens. While these individuals have overstayed their legal status in the U.S., it doesn't justify the claim that they are criminal and as such a threat to the society. Conceptualizing 'them' in a criminal context may lead punishment and deportation to seem a logical consequence due to immoral behavior.

The underlying metaphor is based on what Lakoff defines as 'Strict Father Morality', which describes the conceptual moral system of conservative thinking (1996, p.163). Within this system, 'Moral Authority' sets the rules and determines 
actions as right and wrong. Behavior that does not support this system is considered as immoral and must be punished. Thus, immigrants who have performed an unlawful action by overstaying their authorized legal status are considered as immoral and therefore must be punished.

Moreover, the "us vs. them" scenario has a strong presence within the context of this round of debate, so much that it appears to be lexicalized:

"All these little bills may not amount to huge changes, but they give it the us versus them mentality," says Rachel Yetter, a young woman who works with Valley Interfaith Project in Phoenix and has lobbied to oppose the bills.

These examples illuminate the underlying conceptual thinking that supports the "us vs. them" imperative in which the undocumented immigrant is portrayed as a criminal. Thus imprisonment and deportation seem to be the only moral options for punishment.

$\underline{\text { ALIEN }}$

Similar to the above, the "alien" metaphor is often associated with crime and unlawful presence.

"Criminal aliens are coming to the U.S. in record numbers, said Republican Steve King of Iowa.” (NYT, March 31, 2007)

"Senator John Cornyn, Republican of Texas, has repeatedly urged the administration to take action against such alien absconders." (NYT, August 10, 2007)

Here as well, the Strict Father Morality is influencing the underlying conceptualization of "aliens". Illegal and criminal aliens are breaking the law and should be punished for their wrongdoing. While the literal meaning of the term "alien" means someone from a foreign country, the metaphorical use of this term 
conceptualizes the immigrant as the "other" with a negative connotation.

Generally, we are more accepting of the people who are like us and we are familiar with them. More often than not, we associate aliens with evil intent who are after taking over our land and power. Although this metaphor is not one of the frequently used tokens, its appearance adds a negative glance of immigrants in the context of this debate.

ANIMAL

This trope has been identified as racist in previous studies (Chilton \& Ilyin, 1993; Santa Ana, 1999; Semino \& Masci, 1996) and continues to be present within this discourse. It conceptualizes immigrants as animals who have "flocked" and can be "rounded up" and "lured".

"Scott Stanzel called it a negotiating document. 'It is neither wise nor realistic to round up and deport millions of illegal immigrants, and the president believes this issue should be addressed without amnesty and without animosity', he said" (USA Today, April 19, 2007)

"They say that such attitudes led to the 2000 case in which two white men lured two Mexican day laborers to an abandoned warehouse with a promise of work and then beat them" (New York Times, March 1, 2007)

"Immigrants, many of them illegal, have flocked to evangelical congregations, and evangelical pastors understand that immigration changes increasingly affect their congregants directly" (NYT, May 8, 2007)

Furthermore, these "animals" can be "hunted down" and "ferreted out":

"Administration officials said they were also planning to step up efforts to arrest and deport illegal immigrants who were members of street gangs. And they said federal agents would fan out across the country to hunt down alien fugitives who have been ordered to leave the United States but failed to comply" (NYT, August $10,2007)$

"But critics say the stepped-up enforcement is aimed more at finding votes on Capitol Hill than ferreting out wrongdoers" (CSM, March 13, 2007) 
The findings of this study further confirm that the use of these metaphors continues to exist throughout this discourse. The conceptualization of immigrants as "animals" is argued as racist (Santa Anna, 1999) and further strengthens the claim that immigrants are not one of "us".

\section{OBJECT}

The following are some examples of the "object metaphors" identified in this study:

"Farm worker shortages in the range of 30 percent resulted in crop loss and decisions to scale back operations" (CSM, March 13, 2007)

"Steve Levy, the Suffolk County executive, called for anti-loitering legislation to clear day laborers off the streets" (NYT, March 5, 2007)

This metaphor conceptualizes immigrants as impersonal and

interchangeable objects. Furthermore, immigrants are compared to material such as cheap labor that can be replaced easily.

\section{DANGER TO THE IMMIGRANT}

This metaphor also derived from an open coding of the text. In the below example, two metaphors are identified, namely the "us vs. them" and the newly emerged "danger to the immigrant" metaphor.

"Anytime you have someone who shouldn't have been here in the first place, someone who's violated the law, they should be looking over their shoulder," says Ira Mehlman, a spokesman for the Federation for American Immigration Reform. "They should be nervous and not be made to feel comfortable here."

As explained in the above section, one of the assumptions underlying the "us vs. them" imperative is that immigrants have performed an immoral act by overstaying their 
legal status. Thus immigrants should "look over their shoulder" to see if the legal authorities are behind them in pursuit. The chase from legal authorities is a form of punishment causing the immigrant to always fear who might be "behind their shoulder".

\section{Immigration Policy and Enforcement}

\section{AMNESTY}

The proposed immigration reform included an opportunity for undocumented immigrants to earn citizenship by paying a penalty and fulfilling other requirements. Although the proposed program required undocumented immigrants to receive their citizenship in return for paying a penalty and applying from their home country, the term amnesty wrongly refers to immediate pardon without having to earn legal status in the United States. Furthermore, the term 'amnesty' can have the entailment that foreign individuals are rewarded for breaking the law by overstaying their legal status in the United States. Thus AMNESTY not only misrepresents the proposed changes, but also leads the discussion to a different angle. It lacks validity and adds a negative connotation to the context of the proposed policy. For example, consider the following quote from Mark Kirkorian, Executive Director of the Center for Immigration Studies (CSM, March 13, 2007):

"The Bush administration is pursuing a spoonful of enforcement to help the amnesty go down. It is transparently an effort to provide political cover for House members to vote for an amnesty. Nobody believes that this enforcement will continue beyond the ink drying on the bill."

Another quote from McCain states:

"Pandering for votes on this issue, while offering no solution to the problem, amounts to doing nothing. And doing nothing is silent amnesty" (CSM, June 9, 2007). 
The term AMNESTY is primarily quoted by opponents of the proposed legislation, although journalists occasionally make a reference to it. It appears to be not entirely accurate and adds a negative twist to the context of the debate in order to oppose the bill.

\section{CONTAINER}

The CONTAINER metaphor is a common metaphor within the immigration discourse (Charteris-Black, 2006). It is often used to refer to the nation as what is inside the container, which must be protected and kept secure from external dangers. Consider the following example from the Christian Science Monitor (March 13, 2007):

"Both the House and Senate bills that passed in the last Congress stepped up border security, including a fence along hundreds of miles of the border with Mexico", "In South Carolina this weekend, McCain told a rally that the US needed a temporary work program to help secure the borders but that workers would need to go back home."

The above container metaphors highlight the boundaries of the country and emphasize that what is inside belongs to the nation and what is outside the container does not belong to the country and will need to eventually get out of the nation boundaries. Therefore the borders will need to be secured in order to disable the outside world from entering the country without permission. An alternative metaphor that might structure the concept of increasing security around the container is the underlying metaphor MORE IS UP. The basis for this metaphor is our physical and cultural experience, which entails that increased border security is better. 
Similarly, the following example carries the entailments of protecting the inside from outside foreign sources: "Beef up the border, and fewer will make it into the U.S. in the first place" (CSM, June 29, 2007). Here again an emphasis is placed on reinforcing the boundaries that separate the inside from the outside and therefore making it harder for the people who are not invited to enter the country.

The external world or what is outside the container is portrayed as harmful to the nation or what is inside the container. For example, a quote from NYT (April 29, 2007) states: "Many of these people are serious, violent offenders, and I want them out of our communities and in federal detention centers now." The metaphorical mapping that plays a role in the construction of the container metaphor is that forces from outside build a pressure on what is inside the container. In this example, undocumented immigrants are compared to dangerous criminals who are invading peaceful communities and disrupting the regular course of life. Such turmoil caused by unwanted outsiders creates a feeling of anger toward the outside forces.

\section{INCREASE}

The underlying metaphor of this category assumes that GOOD IS UP as well as

\section{MORE IS GOOD.}

"Stepped up enforcement on businesses that hire illegal workers, including highprofile raids, are drawing more business groups into this year's immigration fight." (CSM, March 13, 2007)

"The Senate proposal, which also calls for increased border controls..." (WP, June 3, 2007) 
The entailments of these metaphors highlight the positive aspects of our experiences with being "up". Generally, "up" is better, happy, and good. Thus the increased enforcement is a positive step toward solving the immigration problem.

\section{Debate About Immigration Issue}

DISEASE

Within the context of this debate, the DISEASE metaphor was identified in association with the issue of immigration rather than the immigrant.

"The president signaled his readiness to take on an issue many here see as toxic". (CSM, April 11, 2007)

In the above example, the immigration issue is conceptualized in terms of a disease that is toxic. This trope evokes the entailment of having adverse effects on a politician's career. The immigration issue is poisonous and most politicians stay away from it because it is contaminating.

\section{ORGANISM}

This metaphor compares the social community to the physical body as the following examples suggest:

"But Professor Gerstle points out that immigrant families who helped populate the city over the last 40 years have become part of its lifeblood.

"The country can't simply throw up its hands and say, 'we've done it this way for the past few generations, so we just should go on doing it'." (NYT, May 30, 2007)

"They have been facing deportation orders since then." (NYT, August 3, 2007) 
There were no particular instances that related to disease or physical discomfort as such. The human body is merely used as a means for comparison. The following examples relate the human body to the legislation itself.

"That approach has left supporters of the bill in the awkward position of at once holding their noses while beating the drums for it" (NYT, June 14, 2007)

"But already some of the less contentious pieces of the bill are returning to life." (NYT, August 3, 2007)

The ORGANISM metaphor is identified from previous studies that analyze the immigration discourse from the early $20^{\text {th }}$ century. This metaphor appears occasionally throughout this research. This further supports the claim that metaphors are prone to change over a period of time.

\section{PERCEPTION}

Tropes within this category refer to how things are viewed and perceived.

Generally, darkness is perceived as negative and brightness as positive. Some of the examples are listed below:

"Taking a pragmatic view on a divisive issue, a large majority of Americans want to change the immigration laws to allow illegal immigrants to gain legal status." (NYT, May 25, 2007)

"Between April 27 and May 17, 350 hearings were held for suspected illegal immigrants who'd been referred for a closer look." (CSM, May 22, 2007)

"While the senators and Bush administration officials exchanged congratulations on Capitol Hill for reaching the compromise, supporters and opponents of illegal immigrants eyed the politicians warily and prepared for a legislative showdown as the proposal heads to the Senate floor this week." (WP, May 21, 2007) 
The majority of the metaphors in this category conceptualize the political process and the debate over the proposed legislation is viewed and perceived. There are no references to immigrants or immigration process as such.

\section{STRUCTURE}

This metaphor was used to conceptualize an understanding of the discussion over the proposed immigration changes.

"The new bill replaced earlier House legislation that sought to strengthen and strictly enforce federal laws targeting illegal immigrants in an effort to encourage them to leave the country" (WP, March 29, 2007)

"This bill is compromising to the country's economy, national security and very foundation of a democracy rooted in the rule of law." (WP, May 22, 2007)

"But with advocates splintered over tactics, the crowds paled in comparison with the turnout last year." (NYT, May 2, 2007)

Likewise, the "structure" metaphors were used to in the context of the legislation debate. Most of the examples refer to the "strengthening", "foundation" as well as "building" of arguments, law and the political system.

\section{HEAT}

The "heat" metaphor primarily conceptualizes the tension between the main stakeholders of the foregoing debate.

"Many conservatives say the bill grants illegal immigrants amnesty, a word that sparks outrage in many parts of Virginia" (Washington Post, June 29, 2007)

"Indeed, the city had been under pressure to formalize a longstanding policy that police officers would not ask for the immigration status of a person who reported a crime" (NYT, March 5, 2007) 
The term "spark" and "pressure" create a schema that conceptualizes the intensity level of the political debate. The conceptual source domain HEAT entails an intense state of emotions. Again, this intensity was mainly in reference to the debate itself.

\section{DECREASE}

In general, the "decrease" metaphor was used to refer to falling short and regressing as oppose to making a progress and moving forward.

"Bipartisan plan in danger as McCain pulls away" (WP, May 15, 2007)

"Salas said the point system that rewards workers is a step back from the 1965 immigration act that widened quotas...." (WP, May 21, 2007)

The "decrease" metaphor conceptualizes the current state of the debate over immigration. The underlying conceptual metaphor is BAD IS DOWN. Thus, "pulling away" and "stepping back" seems to be a regression and not a progress toward an ultimate goal.

\section{SPORTS/GAME}

This trope uses "sport" and "game" metaphors to conceptualize the debate over the immigration issue.

"One of the most interesting, and possibly decisive, tugs of war in the immigration policy debate is happening largely beneath the radar of this nation's media organizations" (USA Today, August 7, 2007)

"The proposed bills would create a guest-worker program and a path to citizenship for illegal migrants. Congress: It prepares to tackle reform again" (CSM, March 13, 2007)

In order to make the political aspect of the debate more understandable for readers, political football or "tug of war" is used as a metaphor. Some possible entailments that are present with this schema are kicking, pulling, force, players, etc. This 
trope is mainly used to make the debate of the new proposed legislation more understandable.

\section{Potential Schemas}

The newspaper articles that were analyzed during this period of time consistently suggest that a comprehensive immigration reform is needed and that the problems with immigration are related to the approximately 12 million "illegal immigrants" living in the United States. In particular, an emphasis is placed on the importance of securing the southern U.S. Mexico border to reduce illegal immigration and enhance the security of American citizens in the United States. On the other hand, there are also arguments in favor of a more supportive immigration law allowing more foreign workers into the country and providing a path to citizenship for undocumented immigrants currently in the United States. The strategic role of some of the prominent immigration metaphors in activating schemas to influence how people think about the issue is analyzed in the following section.

The term "illegal alien" is a frequent metaphor used to refer to immigrants who are in the United States without legal permission. The term "illegal" is often used within a crime context where the immigrant is described as unlawful and felony, which subsequently must be punished by arresting, detaining or investigating the illegal immigrant. Consider the following quotes:

"We don't enroll illegal aliens, said Jeff Hanna, a spokesman for the University of Virginia."(WP, 08/30/07:39).

"Senator John Cornyn, Republican of Texas, has repeatedly urged the administration to take action against such alien absconders" (NYT, 08/10/07:25). 
"Criminal aliens are coming to the U.S. in record numbers (Republican, Steve King of Iowa)" (NYT, 03/31/07:24).

"Those measures would pardon immigrant lawbreakers and reward them with the object of their crimes" (NYT, 05/09/07:72)

"He cited Benjamin Franklin's complaint that German immigrants in Pennsylvania had made his home 'a Colony of Aliens, who will shortly be so numerous as to Germanize $u s$ instead of our Anglifying them'...." (NYT, 03/31/07:54)

Possible entailments of these metaphors are associated with criminality and otherness. First of all, the term "illegal" identifies the problem as a legal issue. An act has been performed against the law and therefore persons who commit such act must be punished for their wrongdoing. Similarly, a crime is an illegal act that is forbidden by law and thus the offender is liable for punishment by that law. The second quote above compares undocumented immigrants to prisoners who have done something unlawful and are escaping their punishment. In general, the existing frame in our mind relates an illegal act with a criminal act and as a result punishment is justified. Because this schema is well established in our cognitive context, it is easy for the reader to identify the above metaphor with a similar existing frame and try to form a perception of the situation in his mind.

Secondly, the term 'alien' further reinforces the illegal frame while also emphasizing the otherness of the immigrant. The Merriam-Webster dictionary defines “alien" as "belonging or relating to another person, place, or thing; strange; and foreign". An article from the Encyclopedia Britannica provides an older definition of "alien" as an enemy, criminal and outlaw. I believe that the older meaning of this term is still prevalent 
which carries negative as well as criminal associations of the term. Nonetheless, both definitions classify the "alien" as the other and not one of us.

It should also be noted that the term "illegal alien" is also understood as a metonymic reference within the context of immigration discourse. As such, "illegal alien" can be directly associated with holding unlawful presence in a foreign country. Similarly, in national and international law, the term "alien" refers to someone who is not a citizen. The Immigration and Nationality Act (INA) consistently refers to the foreign individual as "alien". Therefore within the field of immigration law the term "alien" does not have a metaphorical meaning and may not activate the relevant schemas associated to otherness and criminality as explained above.

In addition to the reference to "illegal alien", the need for security and protection have a potential influence of activating relevant schemas to influence how people think about the immigration issue. It is primarily built upon the underlying "container: metaphor. This metaphor is often used to refer to the nation as what is inside the container, which must be protected and kept secure from external dangers. Thus the boundaries of the container must be secured from outsiders and terrorists. Consider the following examples:

"Some at yesterday's event said they feared that terrorists would slip through improperly protected borders or that legal workers would increasingly lose jobs to an illegal workforce" (Washington Post, 0/17/07:15).

"Beyond the cost, Mr. Spano said public safety was at risk. 'Having these individuals in our communities is a serious and ongoing threat to the safety of our residents', he said" (NYT, 04/29/07:27).

"Until you have the border secure, you cannot deal with the 12 million here without encouraging others to come across" (CSM, 06/28/07:50) 
"The crisis of illegal immigration threatens not only our economy and our security but our very identity", Tancredo said in a statement released by his campaign. (USA Today, 04/03/07:7)

The "container" metaphor entails the need for greater border security to avoid entry of additional illegal immigrants as well as terrorists who are a threat to our communities and identity. Furthermore, people who do not belong in the container should leave, thus "illegal aliens" who are currently in the U.S. should be deported. The security schema refers to a crisis that is caused by outsiders who are invading our country and jeopardizing the safety of American citizens. The threat and fear that is created in turn justifies the need and the cost for greater border security and therefore a shift toward a more restrictive immigration policy.

Boroditsky \& Ramscar (2002) assert that people's spatial thinking and experiences influence their understanding of abstract concepts such as time. Let's apply this claim to the above explained security schema which is based on the underlying CONTAINER metaphor. If we conceptualize NATION AS A HOUSE, which is built on the CONTAINER metaphor, we become automatically more selective as to whom we want to include in our limited and private space. Likewise, we become more protective of the people who are in our "house" and "container". We like to protect our house from outside forces that could disturb the harmony in our familiar space. It appears that our spatial thinking does have an effect on how we conceptualize the abstract domain of immigration although future research needs to support such claim.

The potential schemas evoked by the "illegal alien" reference provide a structured framework for conceptualizing immigrants/immigration as well as proposed policy 
enforcements to solve the problems associated with immigrants/immigration. The term "illegal alien" establishes the context within a criminal framework and carries the entailments of unlawful and felony. As a result, the alien must be punished by being arrested, detained or deported in order to solve the problem. The use of this metaphor triggers consistent structures within the existing schemas which subsequently leads to the inference that a criminal person must be punished for unlawful action (Thibodeau and Boroditsky, 2011).

\section{Summary}

The quantitative analysis provides important information about the relative distribution of previously identified and emergent metaphors among the various categories. The findings also reveal meaningful patterns of differences and similarities between the metaphors used in the immigration debate of the early 20th century, contemporary U.S. and the late $20^{\text {th }}$ century debate in Europe. The most prevalent group of metaphors dominating the U.S. immigration discourse in the early 20th century include categories such as organism, object, animal, natural catastrophe and war. O'Brien's (2003) study demonstrates that these metaphors were designed to construct potential schemas to support restrictive immigration policies in order to reduce the number of incoming immigrants based on race and ethnicity. The industrialization period caused a rapid change to the culture and as a result created a fear amongst the U.S. population. According to O'Brien, the strategic use of these metaphors reinforced this fear.

Most of the dominant metaphors of the early $20^{\text {th }}$ century are insignificant in contemporary immigration debate in U.S. These metaphors appear occasionally throughout the sample text in reference to the debate and the political issue itself. Similar 
to the debate of early $20^{\text {th }}$ century, dominant metaphors depict an image of immigrants that often leads to develop a fear in association with immigrants and immigration. While the earlier debate used disease and contamination as a primary focus to establish that immigrants are divergent, today's discourse focuses on the construction of the enemy invading our country. There is a clear change in the use of metaphors that shape the contemporary immigration discourses although the overall objective of restricting immigration avenues remains the same as the earlier period of time. Despite the similarities, the emergent metaphors identified in the present study appear to be unique to the contemporary debate in the U.S. Particularly metaphors such as "journey" and "danger to the immigrant" have not been distinguished in the context of earlier U.S. debate or the current European discussion. Moreover, metaphors about the current U.S. debate itself seem to be unique to the recent debate in the U.S. and do not appear in other contexts.

The fear-invoking language is also present in the contemporary immigration debate in Europe. The focus appears to be on the desire to preserve national identity. Similar to the immigration debate in the U.S. during earlier and contemporary times, the large flow of immigrants creates an overwhelming feeling that leads to a need for protection of the social identity from the strange "other". In particular, there is animosity toward illegal immigrants and asylum seekers, also referred to as "fortune seekers". 


\section{Discussion}

In this study, I have looked at the immigration discourse of the most recent debate in 2007 and identified common metaphors and themes that could be potentially influential in structuring the discourse and public's understanding of the issues as well as the proposed changes discussed in the debate. The study also illustrates potential influences of immigration metaphors and the schemas they activate on how people think about the issue. As a means for comparison, the literature review section provides an overview of the prominent immigration metaphors used in the early $20^{\text {th }}$ century and the debate in contemporary U.S. and Europe. A comparison of the immigration debate in different contexts allows us to see to what extent cultural and political differences and similarities shape the formation of public's perception of immigration issues.

\section{Comparisons}

A review of the most prominent figurative language used during each period of time in different contexts reveals that dominant metaphors evoke a general feeling of fear. The immigration discourse of the early $20^{\text {th }}$ century conceptualizes immigrants primarily in terms of infectious disease. The underlying metaphor ORGANISM describes immigrants as a contagion as well as a threat to the American society. Similarly the contemporary U.S. discourse provokes a feeling of anxiety caused by the invasion of ALIENS, ENEMIES and TERRORISTS. Within the context of the European debate, fear is created by the prevailing focus on the overwhelming number of immigrants, asylumseekers as well as the threat of terrorists. The fear in messages conveyed in the United States is similar to the immigration related anxieties that exist in the European context of this debate. 
In addition to fear, the need for protection from the "other" is another common similarity among various discourse contexts. The media's construction of the "other" group is particularly dominant within the European context in which the negative "other" presentation is reinforced by the positive "self-representation". The "us vs. them" imperative activates schemas on how people think about the immigrant groups. While in the earlier times the immigrant's refusal to assimilate was used by the media to distinguish the "otherness", the contemporary and most recent debate portrays the immigrant as invader and the enemy. The portrayal and presence of the "other" creates a feeling of uneasiness that leads to the need for protection of national "we".

The fear-invoking themes and the need for protection go hand in hand with the nation's desire to provide public security and preserve national identity. This common theme exists throughout the context of all the debates. The overwhelming rush of immigrants posed a threat to the American character in the early $20^{\text {th }}$ century. Similarly the contemporary U.S. debate reinforces the need for greater border security. Lastly, the European debate focuses on the importance on protecting the borders from recent terrorist attacks as well as the large number of asylum seekers. The security theme is built on the underlying CONTAINER metaphor, which refers to the nation as what is inside the container. The boundaries of the container must be secured from outsiders and external dangers. The large flow of immigrants and asylum seekers poses a threat to our communities and identity.

\section{Contrasts}

While national identity is characterized as important during the early $20^{\text {th }}$ century U.S. debate, the contemporary U.S. debate does not put the main focus on preserving 
national identity. The European debate appears to place a high level of importance on national identity. One of the reasons might be due to the political agenda to retain national sovereignty over immigration and asylum issues within the EU.

Another difference throughout the context of the debates appears to be the conceptualization of asylum seekers in the U.S. and Europe. The primary difference that constitutes for the high level of concern within the European debate is the availability of welfare for asylum seekers in Europe. While asylum seekers in Europe are eligible for government support for an extended period of time, refugees in the U.S. receive financial assistance for a very limited amount of time. As such, asylum seekers are often compared to a burden on the government or "fortune seeker" in the contexts of the European immigration debate.

Lastly, metaphors about the debate itself appear to be unique to the contemporary U.S. discourse. While most of the identified metaphors can be classified as part of a more restrictive frame (war, container, illegal alien), the "journey" metaphor adds a new positive spin to this debate. In general, the "journey" metaphor creates a positive context in which immigrants are to come "out of the shadow" and follow a "path to citizenship". Sport/game metaphors have also not been previously identified within this context. Metaphors such as "crowded field", "shouting match", "case ended in a draw", "tugs of war", "victory of fear", "tackle" and "play by the rules" were among the most commonly used.

The comparison of the figurative language used in different contexts provides us with an insight of some of cultural and political similarities and differences that shape the formation of ideologies. Fear-invoking language, need for protection from the "out- 
group" and public security from external danger are common themes that have dominated the immigration discourse throughout the years in the U.S. and the European immigration debate. While the general themes of the immigration debate in different political and cultural contexts are similar, some themes appear to carry more importance in the European debate. For example the discussion about preserving national identity and the concern about welfare costs appear to be more important in the European context. Furthermore, metaphors about the immigration debate itself that appear in the most recent round of discussion appear to be unique to the contemporary U.S. context. 
Table 2: Representative quotes for major groupings of immigration metaphors

Conceptual Metaphors

Representative quote (s) about immigration (from literature review)

Organism

(Immigrant as diseased

Organisms)

"We have begun to gag a bit over the size and quality of the dose."

"Is it simply, that the food is strange and alien, or does it possibly contain poisons against which we have no antidote?"

"Until the foreign blood we have is absorbed so that it is made American, a further transfusion is anything but desirable."

(O’Brien)

Object

(Immigrant as material)

"We have got to take out the lumps or break them up and smooth out the mass."

"Emergency legislation to protect commerce and industry by preventing the dumping of foreign goods upon the American market, ....the opponents of the (1921) immigration bill would deny like protection to the workingpeople and would permit the dumping of foreign labor in unlimited quantities upon the American market. Why should this nation become a dumping ground of human material any more than a dumping ground of cheap-labor goods?"

(O’Brien)

Natural Catastrophe

"Incoming tide threatens to overwhelm us with the magnitude and ceaseless oncoming of its flood."

"The flood gates will be down and a turgid sea of aliens will inundate our seaports."

"It's a ceaseless ebb and flow, a vast tidal river of labor, of homeless peasantry, surging in, surging out, backing up a bit in winters and slack seasons, and boiling out again like a massive sheet of water over a dam at the onset of prosperity in the spring." (O’Brien) 
War

(Immigrant as Invader)

Animal \& Subhuman Immigrants are Animals
"Armies equal in size to the one we sent to France land every two years on our shores."

"....the invader should come in warships instead of in the steerage hold of steam vessels before the migration can be called an invasion?"

"..like the hordes of old they are destined to conquer us in the end, unless by some miracle of human contriving we conquer tem first." (O’Brien)

"Once the electorate's appetite has been whet with the red meat of deportation as a viable policy option, the slope toward more aggressive ways of implementing that policy is likely to get slippery." (Santa Ana)

"Beaten-down (INS) agents, given only enough resources to catch a third of their quarry, sense the objective in this campaign is something less than total victory." (Santa Ana)

"A wiggling, squirming mass of humanity lay exposed...like a nest of venomous snakes."

"A big swarm of mosquitoes, infested with malaria and yellow fever germs" (O’Brien)

Enemy
"The people of California have suffered and are suffering economic hardship caused by the presence of illegal aliens in this state."

"That they have a right to the protection of their government from any person or persons entering this country unlawfully."

"If we ignore the flood of illegal immigration, we'll erode the quality $f$ life for those who live here legally....our classrooms are bursting, our public health-care facilities are swamped, but the budgets for our parks, beaches, libraries and public safety will continue to suffer while California spends billions to incarcerate enough illegal aliens to fill eight prisons. It is hard working legal immigrants who suffer most from our failure to deal with illegal immigration." 
Us vs. Them

Container

Weed
Use of indexical expressions or deictic markers such as 'we' and 'here' create a shared sense of community while 'us' and 'them' can be used to exclude and insult. Their gain is our loss. This condition is represented as us v. them. For example:

"While our own citizens and legal residents go wanting, those who choose to enter our country illegally get royal treatment at the expense of the California taxpayer."

"The people of California have suffered and are suffering economic hardship caused by the presence of illegal aliens in this state... and illegal immigrants take jobs away from law abiding citizens.....illegal aliens are an overwhelming drain on the State's social services.” (Mehan)

"Britain is full up and the government of Britain has as its first responsibility the welfare, security and long-term preservation of the native people of Britain." (CharterisBlack).

"To defeat the terrorist threat, we need action not talk action to secure our borders. Action to secure our borders will also help in the fight against crime."

"The British people are embroiled in a long term cultural war being waged by a ruling regime which has abandoned the concept of 'Britain' in pursuit of globalization. We are determined to win that cultural war, and to that end, we must take control of our national borders (CharterisBlack).

"...take children of immigrants and their dream hostage in a crude scheme to uproot their parents...."

"And while 33\% said they believed the new crop of immigrants have inferior job skills and education than did their predecessors."

“...spring up among us a generation of ignorant and troubled children who, lacking our common language and political and social ideals, will evolve into a huge, parallel underclass." 
Table 3. Immigration Tropes

Tropes Example

Journey "The Senate immigration proposal is to let illegal immigrants step forward and start down the path to legalization and, eventually, US citizenship". (CSM, 05/21/07:3)

"In a first stage, to begin six months after the bill became law, illegal immigrants would come forward to register with the Department of Homeland Security. (New York Times, 05/22/07:25)

"They know that only a plan that offers a path to earned citizenship will fix our broken system" (USA Today, 04/19/07:8)

"Allowing illegal aliens to circumvent the rule of law not only undermines the integrity and wellbeing of our society and stretches thin limited taxpayer resources at all levels of government, but is an injustice to those immigrants who followed the lawful path in coming to Virginia and the United States, Howell said" (Washington Post, 08/30/07:22)

"Howell and Stosch say they are ready to go much further" (Washington Post, 08/30/07:35)

"For now, this city is marching steadily toward becoming a safe haven for immigrants, whether they are in the country legally or not.

"Mr. Specter said he still supported last year's Senate bill, allowing guest workers and illegal immigrants to move toward citizenship" (NYT, 03/23/07:38)

War "Any deal will be criticized as amnesty by people who want to kill it, and some groups will fight anything that reduces family-based categories". (CSM, 05/21/07:50)

"This battle over immigration is really to define the nation". (USA Today, 04/03/07:13)

"As immigrants marched in Washington, Chicago, Phoenix, Dallas and Los Angeles last year, Morial said he was torn between an urge to advocate for immigrants and an urge to guard against the impact of illegal workers on black unemployment" (Washington Post, 03/23/07:38)

"It becomes a kind of mercenary thing". (Washington Post, 05/22/07:27)

“A day after New Jersey's attorney general, Anne Milgram, ordered local law enforcement agencies to start inquiring about the immigration status 
of the people they arrest, local officials and advocates for immigrants across the state began grappling with how the edict would change the already complicated relationship between the authorities and immigrants on the streets they patrol" (NYT, 08/24/07:6)

"When a comprehensive immigration bill collapsed last month on the Senate floor, it was a victory for a small group that had been lobbying Congress for a decade to reduce the number of immigrants -legal and illegal- in the United States" (NYT, 07/15/07:1)

Container "Until you have the border secure, you cannot deal with the 12 million here without encouraging others to come across". (CSM, 06/28/07:50)

"Shut down the rides, turn down the lights, the crowd goes home". (CSM, 06/29/07:22)

"The crisis of illegal immigration threatens not only our economy and our security but our very identity", Tancredo said in a statement released by his campaign. (USA Today, 04/03/07:7)

"It is an ambitious package made up of interlocking components intended to work together to create a new immigration system that will secure the nation's borders, provide a path to legal status for an estimated 12 million illegal immigrants..." (New York Times, 05/22/07:9)

"Opponents said the government was throwing up a barrier to legal immigrants to naturalize" (Washington Post, 03/29/07:32)

"With Congress considering a bill to bolster border security and give millions of illegal immigrants a chance to eventually become citizens, Virginia Republicans..." (Washington Post, 06/28/07:8)

"The increase 'presents a huge barrier to thousands of immigrants' anxious to vote in the 200 presidential primary and general elections, said Eliseo Medina, the union's executive vice president" (Washington Post, 08/28/07:14)

"The sheriff said that when people were arrested who could not show any legal residency status, 'the majority of them admit how they got in, believe it or not'.." (New York Times, 03/01/07:58)

"Many of these people are serious, violent offenders, and I want them out of our communities and in federal detention centers now" (NYT, 04/29/07: 28) 
"Bush laid out his argument in support of that plan Monday, during a stop at a newly fortified border crossing in Yuma, Arizona"

(CSM, 04/11/07)

"For too long, Americans have been force-fed candidates who ignore or mock their valid concerns about the security of our borders, the enforcement of our immigration laws, and the survival of our national heritage," says Rep. Tom Tancredo of Colorado. (CSM, 04/11/07).

"Senate immigration bill calls on the administration to substantially reduce illegal immigration and greatly improve border security by rigorously enforcing existing laws" (CSM, 06/21/07)

Water "Critics fear a flood of recruits lured solely by the promise of legal status" (Washington Post, 05/22/07:24)

"The recent wave of immigration was the largest invasion in the history of the world". (Washington Post, 06/17/07:10)

"Last week, apple growers were the latest wave of business groups on Capitol Hill to lobby for immigration reform" (CSM, 03/13/07:19)

"Now you are seeing waves in bigger and bigger numbers that they do indeed want to participate" (CSM, 03/26/07:57)

"US Immigration officials caution against misinterpreting the latest rise in applications. Analysis of the past 100 years shows $e b b$ and flows that defy easy explanation, they say" (CSM, 03/26/07:65)

"But even though one in four Fairfax Country residents is foreign born, there remains a sizable voting bloc in the county that has been frustrated by the influx of immigrants over the past two decades" (Washington Post, 06/28/07:44)

"Hazleton made national headlines last year by passing some of the nation's strictest ordinances against illegal immigration, saying that illegal immigrants were draining city coffers but without producing evidence" (Washington Post, 07/27/07:22)

"Bloomberg said: Let 'em come...I can't think of any laboratory that shows better why you need a stream of immigrants than New York City" (Washington Post, 08/16/07:23

“Each wave of 'new' immigrants has been scored...." (NYT, 03/31/07:52) 
"And American history has been marked by waves of xenophobia that ebbed as the new immigrants gained the power of the ballot box" (NYT, 03/31/07:53)

"The proposed law certainly would not end the flow of legal immigration to new York" (NYT, 05/30/07:3)

Us vs. them "A very large number of non-citizens could change the purpose of the military form the defense of the country to a job and a way to get a foot in the door of the United States", (Washington Post, 05/22/07:25)

"Those measures would pardon immigrant lawbreakers and reward them with the object of their crimes" (NYT, 05/09/07:72)

"We need them here in reasonable numbers that allow time for them to become Americans, Lewis said” (Washington Post, 06/17/07:21)

"We want them out of county jails and into federal prisons ASAP, he said" (New York Times (03/01/07:50)

“Immigration experts doubt a city's policies could affect an immigrant's destination more than, say, where relatives live or jobs can be found, but there is at least tacit acknowledgment here that there is political will to try things in New Haven that would be shunned in more conservative communities.

"He cited Benjamin Franklin's complaint that German immigrants in Pennsylvania had made his home "a Colony of Aliens, who will shortly be so numerous as to Germanize us instead of our Anglifying them'..." (NYT, 03/31/07:54)

"Beyond the cost, Mr. Spano said public safety was at risk. 'Having these individuals in our communities is a serious and ongoing threat to the safety of our residents', he said" (NYT, 04/29/07:27)

"It was a David-and Goliath struggle," said Roy H. Beck the president of Numbers USA (NYT, 07/15/07:7)

Aliens "Although not always familiar with such details, many immigrants in the crowd offered clear opinions about why they believe the government needs a workable legalization program, and they strongly disputed critics' claims that this would amount to amnesty for lawbreakers who had sneaked into the United States". (Washington Post, 06/03/07:33) 
"Some at yesterday's event said they feared that terrorists would slip through improperly protected borders or that legal workers would increasingly lose jobs to an illegal workforce". (Washington Post, 06/17/07:15)

"Senator John Cornyn, Republican of Texas, has repeatedly urged the administration to take action against such alien absconders" (NYT, 08/10/07:25)

"Evidence from recent operations, including one last week, shows that not only do these employers hire illegal aliens, but it was part of their business model to hire illegal aliens" (CSM, 03/13/07:37)

"She added: when ICE is carrying out the removal order of an immigration judge, our officers are responsible for the safety of the alien and members of public who come into contact with the alien on a commercial flight" (Washington Post, 06/20/07:26)

"We don't enroll illegal aliens, said Jeff Hanna, a spokesman for the University of Virginia" (Washington Post, 08/30/07:39)

"Criminal aliens are coming to the U.S. in record numbers (Republican, Steve King of Iowa)" (NYT, 03/31/07:24)

Animal "Administration officials said they were also planning to step up efforts to arrest and deport illegal immigrants who were members of street gangs. And they said federal agents would fan out across the country to hunt down alien fugitives who have been ordered to leave the United States but failed to comply" (NYT, 08/10/07:22)

"But critics say the stepped-up enforcement is aimed more at finding votes on Capitol Hill than ferreting out wrongdoers" (CSM, 03/13/07:40)

"Scott Stanzel called it a negotiating document. 'It is neither wise nor realistic to round up and deport millions of illegal immigrants, and the president believes this issue should be addressed without amnesty and without animosity', he said" (USA Today, 04/19/07:26)

"Earlier this year, U.S. Citizenship and Immigration Services, a division of the Department of Homeland Security, caused an uproar by dramatically increasing citizenship application fees and toughening citizenship tests" (Washington Post, 03/29/07:31)

"They say that such attitudes led to the 2000 case in which two white men lured two Mexican day laborers to an abandoned warehouse with a promise of work and then beat them" (New York Times, 03/01/07:58) 
Object "Farm worker shortages in the range of 30 percent resulted in crop loss and decisions to scale back operations" (CSM, 03/13/07:22)

"Steve Levy, the Suffolk County executive, called for antiloitering legislation to clear day laborers off the streets" (NYT, 03/05/07:23)

"Illegal immigrants are imbedded in our nation, so allowing them to apply for a work visa would be a good way to draw them in and set a path for them to become legal, said Mr. Nunez" (NYT, 05/25/07:29)

Disease "The president signaled his readiness to take on an issue many here see as toxic". (CSM, 04/11/07:4)

Plant "The number of naturalized citizens in the United States grew to nearly 13 million between 1995 and 2005" (Washington Post, 03/29/07:1)

"Despite the relatively small number of arrests in Montgomery, immigrant advocates have told Manger that the unexpected deportations have torn families apart and sown fear among immigrants" (Washington Post, 06/13/07:38)

"But his approach has ignited protests and raised old questions about the role of police departments in immigration matters, a thorny part of the rancorous national debate" (NYT, 04/29/07:10)

"The bill aims to reduce legal migration in the future by eliminating family sponsorships outside the overall numbers set by government, and ending the diversity visa, which brings thousands of fresh seed immigrants by lottery to New York each year" (NYT, 05/30/07:59)

"The city's immigration accelerated in the 1970s through a classic pattern of daisy chain migration with 'seed' immigrants sponsoring close relatives who eventually sponsored others.” (NYT, 05/30/07:42)

Organism "Senator Mel Martinez, Republican of Florida, called it a pretty good skeleton of a bill" (NYT, 05/09/07:23)

"But Professor Gerstle points out that immigrant families who helped populate the city over the last 40 years have become part of its lifeblood. 
Table 4. Emergent Tropes

\begin{tabular}{ll}
\hline Tropes & Example \\
\hline Journey & "The Senate immigration proposal is to let illegal immigrants step forward \\
& $\begin{array}{l}\text { and start down the path to legalization and, eventually, US citizenship". } \\
\text { (CSM, 05/21/07:3) ... }\end{array}$
\end{tabular}

Perception "Taking a pragmatic view on a divisive issue, a large majority of Americans want to change the immigration laws to allow illegal immigrants to gain legal status." (NYT, 05/25/07)

Structure "This bill is compromising to the country's economy, national security and very foundation of a democracy rooted in the rule of law." (WP, $05 / 22 / 07)$

Heat "Many conservatives say the bill grants illegal immigrants amnesty, a word that sparks outrage in many parts of Virginia" (Washington Post, 06/28/07:13)

"Indeed, the city had been under pressure to formalize a longstanding policy that police officers would not ask for the immigration status of a person who reported a crime" (NYT, 03/05/07: 37)

"But his approach has ignited protests and raised old questions about the role of police departments in immigration matters, a thorny part of the rancorous national debate" (NYT, 04/29/07:10)

Decrease "Salas said the point system that rewards workers is a step back from the 1965 immigration act that widened quotas...." (WP, 05/21/07)

Increase "Stepped up enforcement on businesses that hire illegal workers, including high-profile raids, are drawing more business groups into this year's immigration fight." (CSM, 03/13/07)

Sport/Game "The new fees send the wrong message to people who want to play by the rules and are willing and able to work toward the American dream" (USA Today, 06/08/07:25) 
"One reason is the stepped up federal enforcement of employer sanctions" (CSM, 03/13/07:27)

"The Bush administration plans to announce numerous steps on Friday to secure the border with Mexico, speed the expulsion of illegal immigrants and step up enforcement of immigration laws, administration officials say" (NYT, 08/10/07:1)

"The proposed bills would create a guest-worker program and a path to citizenship for illegal migrants. Congress: It prepares to tackle reform again" (CSM, 3/13/07:title)

"Ms. Milkman and others note that those seeking naturalization are not in the US illegally. They are 'the ones who have played by all the rules', obtaining green cards and establishing US residency for at least five years" (CSM, 03/26/07:48)

"One of the most interesting, and possibly decisive, tugs of war in the immigration policy debate is happening largely beneath the radar of this nation's media organizations" (USA Today, 08/07/07:1) 


\section{References}

Boroditsky L. \& Ramscar M. (2002). The roles of body and mind in abstract thought. Psychological Science, 13, 185-188.

Boswell, R. A. (2006). Essentials of immigration law. American Immigration Lawyers Association.

Cameron, L. (2003). Metaphor in educational discourse. London: Continuum.

Castan Pinos, J. (2008). Building Fortress Europe? Schengen and the cases of Ceuta and Melilla. CIBR/WP10. Belfast: CIBR Working Papers in Border Studies.

Charteris-Black, J. (2006). Britain as a container: Immigration metaphors in the 2005 election campaign. Discourse Society, 17, 563-581.

Chilton, P. A. (1996). Security metaphors: Cold war discourse from containment to common house. New York: Peter Lang.

Chilton, P. A. \& Ilyin, M. (1993). Metaphor in political discourse: The case of the common European house. Discourse Society, $\underline{4}, 7-31$. 
Del-Teso-Craviotto, M. (2009). Racism and xenophobia in immigrants' discourse: The case of Argentines in Spain. Discourse \& Society, 20(5), 571-592.

Encyclopedia Britannica. http://www.britannica.com/EBchecked/topic/15390/alien.

Entman, R. (2005). The nature and sources of news. In G. Overholser \& K. H. Jamieson (Ed.), The press (pp. 48-65). New York: Oxford University Press.

Herbst, S. (1993). Numbered Voices. Chicago. University of Chicago Press.

Huntington, S. P. (1996). http://en.wikipedia.org/wiki/The_Clash_of_Civilizations

Huysmans, J. (2000). The European Union and the Securitization of Migration. Journal of Common Market Studies, 38(5), 751-777.

Jerolmack, C. (2008). How pigeons became rats: The cultural-spatial logic of problem animals. Social Problems, 55(1), 72-94.

Koevecses, Z. (2003). Metaphor and emotion. Cambridge: Cambridge University Press.

Ladd, E. C., \& Benson J. (1992). The Growth of News Polls in American Politics. In T. E. Mann \& G. R. Orren (Ed.), Media Polls in American Politics. Washington, DC: The Brookings Institution. 
Lakoff, G. \& Johnson, M. (1980). Metaphors we live by. Chicago: University of Chicago Press.

Martin, P. \& Midgley, E. (2006). Immigration: Shaping and reshaping America. Revised and Updated $2^{\text {nd }}$ Edition. Population Bulletin, 61(4) (Washington, DC: Population Reference Bureau).

Martin, R. L. \& Van Dijk, T. (1997). There was a problem, and it was solved: legitimating the expulsion of illegal migrants in Spanish parliamentary discourse. Discourse \& Society, $\underline{8}(4), 523-66$.

Mehan, H. (1997). The discourse of the illegal immigration debate: A case study in the politics of representation. Discourse \& Society, $\underline{8}(2), 249-270$.

Musolff, A. (2000). Political imagery of Europe: A house without exit doors? Journal of Multilingual and Multicultural Development, 21(3), 216-229.

O’Brien, G. (2003). Indigestible food, conquering hordes, and waste materials: Metaphors of immigrants and the early immigration restriction debate in the United States. Metaphor and Symbol, 18(1), 33-47. 
Page, B. I. (1996). Who Deliberates: Mass Media in Modern Democracy. Chicago: University of Chicago Press.

Pew Research Center for the People and the Press, "Online Papers Modestly Boost Newspaper Readership", March 12, 2007.

Price, V., Tewksbury, D., \& Powers, E. (1997). Switching trains of thought: The impact of news frames on readers' cognitive responses. Communication Research, 24(5), 481-506.

Ritchie, L. D. (2006). Context and connection in metaphor. Houndmills and New York: Palgrave Macmillan.

Santa Ana, O. (1999). Like an animal I was treated: Anti-immigrant metaphor in US public discourse. Discourse Society, 10, 191-224.

Schön, D. A. (1979). Generative metaphor: A perspective on problem-setting in social policy. In Anthony Ortony (ed.) Metaphor and Thought, pp. 137-163. Cambridge, MA: Cambridge University Press.

Semino, E. \& Masci, M. (1996). Politics is football: metaphor in the discourse of Silvio Berlusconi. Discourse and Society, 7, 243-269. 
Thibodeau, P. H. \& Boroditsky, L. (2011). Metaphors we think with: The role of metaphor in reasoning. PLoS One, $\underline{6}(2)$ : e16782.

Van Dijk, T.A. (2001). Critical Discourse Analysis, in D. Schiffrin, D. Tannen and H.E.

Hamilton (eds) The Handbook of Discourse Analysis, pp. 352-71. Oxford: Blackwell.

Van der Vilke, I. (2003). Right-wing Parliamentary Discourse on Immigration in France.

Discourse \& Society, 14(3), 309-48.

Wodak, R. (2006). Mediation between discourse and society: Assessing cognitive approaches in CDA. Discourse Studies, $\underline{8}, 179-190$.

Zaiotti, R. (2007). Of Friends and Fences: Europe's Neighbourhood Policy and the Gated Community Syndrome. European Integration, 29(2), 143-162. 